\title{
Colibri e Caranguejo: genealogia e edição de dois choros pioneiros para violão
}

\author{
Colibri and Caranguejo: genealogy and \\ editing of two pioneering choros for guitar
}

Humberto Amorim ${ }^{1}$ Universidade Federal do Rio de Janeiro (UFRJ) amorim@hotmail.com

Jefferson Motta Discoteca Oneyda Alvarenga - Centro Cultura São Paulo (CCSP) jeffersonmotta@ymail.com

Flavia Prando 3 Centro de Pesquisa e Formação do SESC, São Paulo (CPF-SESC) prandoflavia@gmail.com

Ivan Paschoito 4 (Legato) ipaschoito@gmail.com 


\section{Resumo}

No repertório exclusivo para violão, à exceção de algumas obras de Villa-Lobos, ainda são raras e/ou desconhecidas as peças para o instrumento que remetem ao período de consolidação do choro como gênero musical, um processo que se alastrou de meados do século XIX até os decênios iniciais dos novecentos. Na tentativa de colaborar com o preenchimento da lacuna, o presente artigo objetiva apresentar ineditamente dois choros para violão compostos por volta de 1912: Colibri, de Melchior Cortez (1882-1947); e Caranguejo, de Francesco Rosa Gadanho (1872 -?). Em diálogo com trabalhos de referência sobre o tema e através do levantamento de fontes, edições e manuscritos até então desconhecidos, o texto tem como objetivos secundários traçar uma genealogia preliminar das obras e de seus compositores, destrinchar a relação composicional das peças (que podem ser tocadas em versões para solo ou duo), discutir sucintamente algumas das possíveis razões que justificam porque poucas peças do gênero sobreviveram, avaliar possíveis intersecções entre violão e circo no ínterim em questão, bem como analisar de que forma os imbricamentos musicais e a permeabilidade terminológica que rondaram o período de constituição do choro também estão presentes nos subtítulos e no conteúdo musical das peças suscitadas. Finalmente, apresentamos os critérios que nortearam uma iminente edição moderna das partituras, a ser publicada em parceria com a editora Legato. Como resultado, acreditamos que a discussão de tais perspectivas não somente colabora para alargar o entendimento de nossas práticas de outrora, mas também possibilita que novas peças do repertório pioneiro do violão brasileiro sejam paulatinamente incorporadas na literatura do instrumento.

Palavras-chaves: Repertório para violão. Choros pioneiros. Circo e violão. Polca e choro. Edição musical para violão.

\footnotetext{
1 Professor da Universidade Federal do Rio de Janeiro (UFRJ) desde 2007. Doutor em Musicologia, Mestre em Práticas Interpretativas. Tem três graduações na área musical e é Máster em violão clássico pela Universidade de Alicante (ESP). Já realizou concertos, palestras, comunicações e lançamentos em 13 países e publicou um DVD e dois livros pela Academia Brasileira de Música: Tacuchian por Humberto Amorim (2015), Ricardo Tacuchian e o Violão (2014) e Heitor Villa-Lobos e o Violão (2009), este último considerado pela crítica "a maior pesquisa já realizada sobre o assunto no Brasil" (Revista Violão Pro, 2009). Desde 2016, vem publicando uma série de artigos em revistas especializadas, frutos de seu período como pesquisador-residente (20152017) da Fundação Biblioteca Nacional.

2 É mestre em música pela UNICAMP e bacharel em violão pela Faculdade Cantareira. Trabalha na organização das coleções que compõem o acervo da Discoteca Oneyda Alvarenga, entre elas, a Coleção Ronoel Simões e é integrante do coletivo Samba de Terreiro de Mauá.

3 Violonista, doutora e mestre em musicologia pelo Departamento de Música da ECA- USP. Bacharel em música com habilitação em instrumento, vioIão, pelo Instituto de Artes da Unesp. É Pesquisadora em Ciências Humanas e Sociais do Centro de Pesquisa e Formação do SESC em São Paulo, onde desenvolve pesquisas e cursos nas áreas da música, com enfoque em música brasileira.
} 


\section{Abstract}

In the exclusive repertoire for guitar, with the exception of some works by Villa-Lobos, pieces for the instrument that refer to the period establishing choro as a musical genre, a process that spread from the mid-nineteenth century until the early twentieth century, are still rare and/or unknown. In an attempt to help fill this gap, the present article aims to present for the first time two choros for guitar composed around 1912: Colibri, by Melchior Cortez (1882-1947); and Caranguejo, by Francesco Rosa, the Gadanho (1872 -?). In examining reference works on the subject and through the survey of sources, editions and manuscripts unknown until then, the text has as secondary objectives to trace a preliminary genealogy of the works and their composers, to unravel the compositional relationship of the pieces (which can be played in solo or duo versions), discuss briefly some of the possible reasons why few pieces of the genre survived, evaluate possible intersections between guitar and around the period in question, as well as analyze how the musical imbrications and the terminological permeability that surrounded the period of the constitution of choro are also present in the subtitles and musical content of the pieces raised. Finally, we present the criteria that guided an imminent modern edition of the scores, to be published in partnership with the
Legato publishing house. As a result, we believe that the discussion of such perspectives not only contributes to broaden the understanding of our past practices, but also enables new pieces of the pioneer repertoire of the Brazilian guitar to be gradually incorporated into the literature of the instrument.

Keywords: Guitar repertoire. Pioneer Choros. Circus and guitar. Polka and choro. Music edition for guitar.

\footnotetext{
4 Formado em Editoração pela ECA/USP. É violonista e arranjador. Tem publicado nas maiores editoras musicais brasileiras: Cultura Musical, Arlequim, Fermata, Ricordi, Vitale. Nos EUA, na Guitar Solo Publications e SMP Press. São 241 arranjos e transcrições distribuídos em 19 álbuns e em mais de 150 partituras avulsas, impressas ou digitais. Como assessor editorial da Ricordi, preparou a edição do último trabalho de Henrique Pinto - Antologia Violonista - e as reedições do Método Paulinho Nogueira e do primeiro volume de A Escola de Tárrega, de Sodré. E também mais de 20 volumes para outros instrumentos, piano, órgão, flauta e violino, traduzidos e/ou editorados e publicados pela mesma Ricordi. Tem sua própria editora, a Legato, especializada em música impressa para violão, com mais de 100 títulos no catálogo.
} 


\section{Introdução}

Desde a primeira metade dos anos novecentos, diversos estudiosos/as têm se dedicado a investigar o universo do Choro, fato que ganhou contornos ainda mais nítidos na passagem entre os séculos $X X$ e XXI, com a inclusão da pauta nos emergentes programas brasileiros de pós-graduação em música e a disseminação de iniciativas (como a criação de clubes, coletivos, grupos e escolas ${ }^{5}$ em várias regiões do país), dentro e fora da academia, que instigaram uma proliferação ainda maior das pesquisas em torno do tema.

Em 2020 e 2021, tal movimento resultou na aprovação de um Simpósio Temático dentro da programação dos congressos da Associação Nacional de Pesquisa e Pós-graduação em Música (ANPPOM): "Choro no sentido lato", coordenado pelas professoras Cibele Palópoli (UNISANTOS) e Sheila Zagury (UFRJ), em uma inequívoca demonstração da força conquistada pelo tema no panorama dos estudos da área. No texto de apresentação da proposta, e a partir dos conceitos expostos no livro de Ary Vasconcelos (1984), as pesquisadoras distinguem o que seria o choro no "sentido estrito", tomado como gênero musical, do choro "no sentido lato", compreendido como "o repertório dos chorões formado por polcas, tangos brasileiros, valsas, mazurcas, maxixes, xotes e até sambas e marchas", destacando como os diferentes significados do termo vêm sendo abordados de forma crítica, dialógica e cada vez mais aprofundada por uma ampla gama de pesquisadores/as, da Música ou de outras áreas, dentre os/as quais se destacam Aragão (2011) e Zagury (2014). Dada a multiplicidade das visões e abordagens, as coordenadoras indicam que a expressão 'universo do Choro' se tornou "uma das mais comumente utilizadas para, metaforicamente, explicitar a vastidão do assunto"6.

Em sua tese doutoral, a própria Palópoli discute as variadas acepções que o termo "choro" foi paulatinamente adquirindo desde os primeiros estudos a mencionar a temática, recorrendo a uma acurada revisão bibliográfica ${ }^{7}$ para elencar sete diferentes significados para o vocábulo: "1. Conjunto Instrumental, 2. Peça de repertório, 3. Evento social, 4. Sinônimo de músico ou instrumentista, 5. Gênero Musical, 6. Prática musical, 7. Estilo Interpretativo". (PALÓPOLI, 2018, p. 40). ${ }^{8}$ Portanto, podemos sugerir que o Choro, tomado como manifestação cultural mais ampla, tem sido alvo de um número

5 No Rio de Janeiro, por exemplo, o Instituto Casa do Choro (que abriga a Escola Portátil de Música) é uma entidade de Utilidade Pública que atua desde 1999 "no terreno da educação musical, preservação e divulgação da música popular carioca, em especial o choro", com as suas atividades destinadas à "formação de plateias e de músicos profissionais, produção e difusão de shows e eventos, manutenção e conservação de acervos, catalogação, registro e preservação da memória musical.." Fonte: https://www.casadochoro.com.br/

6 Fonte: https://anppom.org.br/xxx-congresso-da-anppom/simposios-e-gts-aprovados/ Acesso: 13 abril. 2021.

7 A autora elencou tais acepções a partir da análise de dezenas de publicações pioneiras e/ou referenciais sobre o tema, em uma faixa temporal que vai de 1907 (com o artigo Folclore Pernambucano, de Francisco Augusto Pereira da Costa) a 1998 (com o livro Choro: do quintal ao municipal, de Henrique Cazes). Dentre as/os autores mencionados, constam ainda: Raul Pederneiras (1922), Jacques Raimundo (1936), Renato Almeida (1942), Câmara Cascudo (1954), Luiz Heitor Corrêa de Azevedo (1956), Vasco Mariz (1959), Curt Lange (1966), Gerard Béhague (1966), Baptista Siqueira (1970), José Ramos Tinhorão (1974), Mozart de Araújo (1977), Ary Vasconcelos (1984), dentre outros. (PALÓPOLI, 2018, p. 37-39).

8 Em função da abrangência e problemas terminológicos que envolvem o assunto, a autora propõe uma possível diferenciação gráfica de acordo com o contexto de utilização: choro, com "c" minúsculo, quando o termo faz menção a um gênero musical específico; Choro, com ' $C$ ' maiúsculo, quando o termo se dirigir a uma manifestação cultural mais ampla, abarcando uma ou várias das múltiplas facetas compreendidas como pertencentes a este universo. (cf. PALÓPOLI, 2018, p. 27-28). No presente trabalho, adotaremos a solução da autora, referência no tema, para distinguir o gênero musical (choro) da manifestação cultural que abriga um universo de práticas mais abrangentes (Choro). 
considerável de estudos, abordagens e perspectivas, algo contínuo desde o início dos novecentos e que se potencializou sobremaneira das décadas finais do século XX até o presente momento.

O aprofundamento e a proliferação de pesquisas em torno do tema também alcançaram decisivamente os estudos específicos de violão, com uma plêiade de pesquisadores/as se dedicando a investigar muitas das múltiplas relações possíveis entre o instrumento e o Choro, desde as transformações estilísticas e das formas musicais atreladas ao gênero (BORGES, 2008; 2008b; 2019), passando pela análise da produção de violonistas emblemáticos (MATEUS, 2006), até publicações que pautam as "baixarias" (CARNEIRO, 2001) e/ou as idiossincrasias do violão de 7 cordas (BRAGA, 2004). Um dado, porém, é o de que tais pesquisas majoritariamente abordam ora os papeis desempenhados pelo instrumento dentro do conjunto, como acompanhador ou como contraponto aos solistas, ora analisam de que forma o instrumento e alguns de seus personagens foram decisivos para promover mudanças e alargamentos estruturais no próprio gênero.

Um dos aspectos ainda pouco debulhados nos estudos da área é a análise de como estes traços históricos de constituição do choro também se relacionaram com a concepção de peças exclusivas para violão, especialmente se considerarmos o ínterim anterior a 1930 como recorte temporal. Muito da lacuna se deve não somente ao fato de que usualmente o instrumento não cumpre um papel solista dentro das formações características do gênero, mas também porque, à exceção das obras amplamente conhecidas de Heitor Villa-Lobos (1887-1959) ${ }^{9}$, ainda são raras e/ou pouco conhecidas as peças do período que nos alcançaram. Palópoli pontua que "há um consenso entre os pesquisadores em atribuir ao início do século XX - mais especificamente, à obra de Pixinguinha - o marco cronológico em que o gênero musical choro foi estabelecido." (2018, p. 31). Borges e Volpe ratificam a perspectiva ao afirmar que a década de 1920 "pode ser situada como o período em que o choro se consolidou como gênero no Brasil." (2020, p. 5). Mas, para além de Villa-Lobos, algum outro repertório brasileiro para violão nos chegou advindo do período de consolidação do choro como gênero musical?

$\mathrm{Na}$ tentativa de colaborar com os desdobramentos dessa questão, o presente artigo apresenta ineditamente dois choros para violão compostos no início do século XX: Colibri, de Melchior Cortez (1882-1947); e Caranguejo, de Francesco Rosa Gadanho (1872 -?). Através do levantamento de fontes, edições e manuscritos até então desconhecidos, o texto não somente traça uma genealogia preliminar das obras e de seus compositores, mas destrincha a relação composicional das peças, discute sucintamente algumas das razões que podem justificar porque poucas peças do gênero sobreviveram e chegaram até nós, discorre sobre as possíveis intersecções entre violão e circo, bem como analisa de que forma os imbricamentos musicais e a volatibilidade terminológica que rondaram o período de constituição do choro também estão presentes nos subtítulos e no conteúdo musical das peças suscitadas.

9 Choros n. $1^{\circ}$ e eventualmente as peças da Suíte Popular Brasileira, se nos valemos da definição de Choro como manifestação cultural mais ampla. 
Por fim, a partir dos documentos levantados, o nosso propósito foi o de conceber uma edição moderna das obras (que podem ser tocadas tanto na versão para violão solo quanto na em duo, conforme veremos a seguir), revisando as fontes e partituras encontradas e abrindo a perspectiva de apresentar, à comunidade artística e científica que gira em torno do violão, dois choros pioneiros do nosso instrumento.

\section{Colibri, de Melchior Cortez (1882-1947) ${ }^{10}$}

Uma das composições mais antigas de Melchior Cortez de que se tem notícia é o choro Colibri, de 1912, publicado pela Casa Romero y Fernandez provavelmente em fins da década de 1920 (1927-1929), período que concentra as peças do violonista que foram lançadas, pela editora argentina, com indicação expressa do ano de publicação
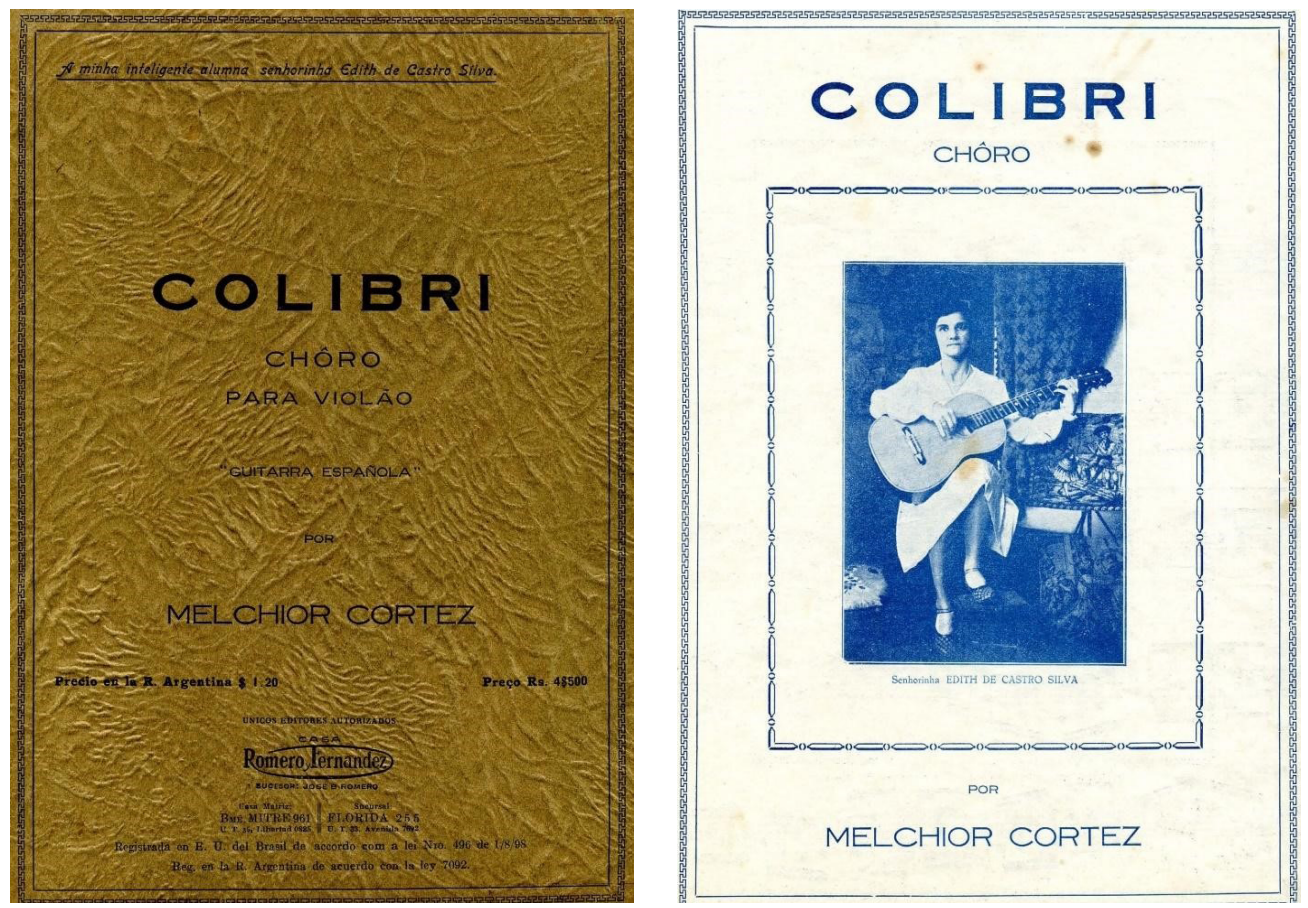

Fig. 1 e 2: Capa e contracapa de Colibri, edição da Casa Romero y Fernandez. Fonte: Cortez [s.d.].

Conforme ocorrera com a maioria de suas obras, Melchior dedica esta peça a uma de suas alunas, Edith de Castro Silva (na foto), uma dentre as muitas mulheres a integrar o grupo de estudantes da Academia Brasileira de Violão que o violonista fundou na década de 1920. A data específica de sua criação só se conhece por meio de uma nota escrita ao pé da primeira página na edição da Casa Romero y Fernandez: "Esta muzica foi feita em 1912 para tocar com o chôro intitulado 'CARANGUEIJO' [sic]." (CORTEZ, [s.d.], p. 2). Isto indica que a obra originalmente fora acompanhamento de um outro choro

10 Personagem cuja biografia e atuação como concertista, professor e autor já foram abordadas por nós em estudos anteriores (AMORIM, 2018a; 2018b; 2018c; 2020). 
tão ou mais antigo do que o de Melchior. De fato, com 48 compassos divididos em três seções, Colibri preserva em todas as suas partes um certo caráter acompanhador, especialmente na seção $C$, construída integralmente por blocos de acordes articulados em arpejos e sem um traço melódico bem definido.
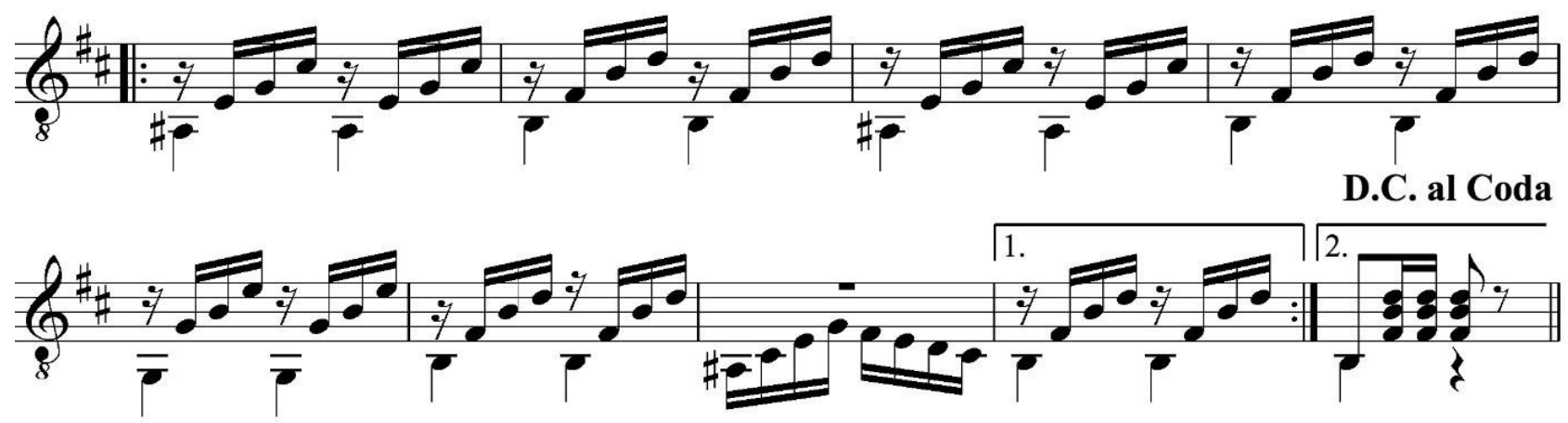

Fig.3: Seção C de Colibri. Fonte: Elaboração dos autores (a).

Nas seções A e B, contudo, sobressalta a utilização do baixo como recurso idiomático, um elemento típico do choro (as "baixarias") e que Cortez demonstra que sabia manipular bem, conferindo-lhe movimento e a condução motívico-melódica da peça.
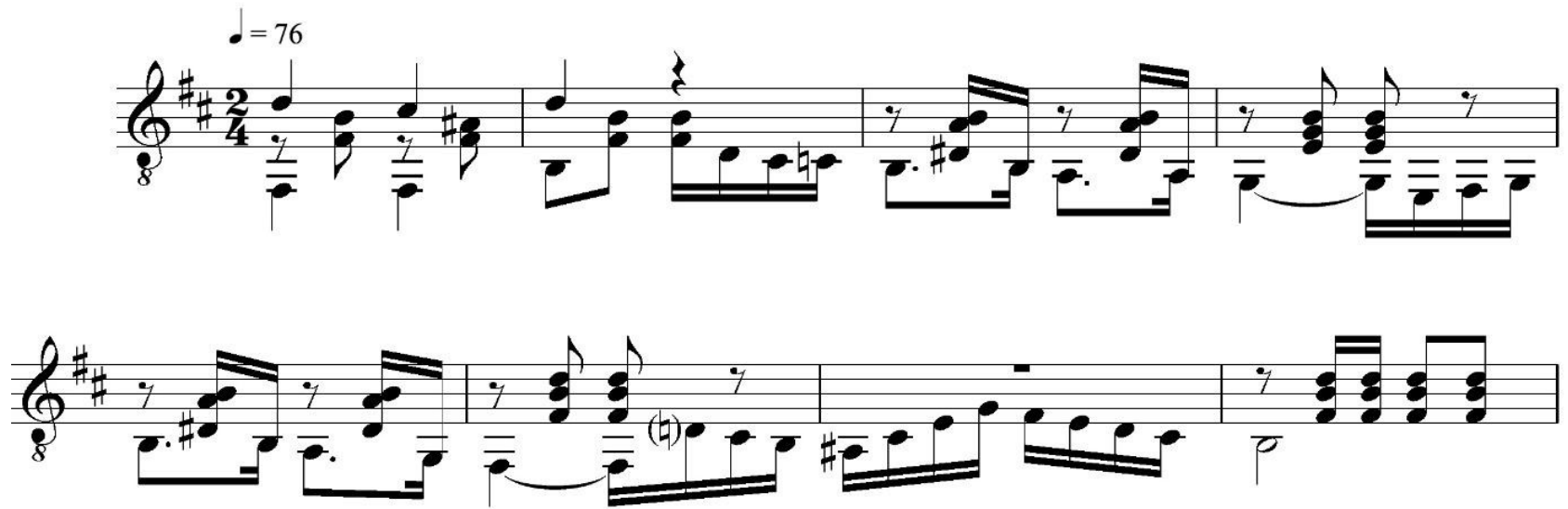

Fig. 4: Seção A de Colibri. Fonte: Elaboração dos autores (a).

Além do uso idiomático dos baixos, a peça se destaca por ser um dos primeiros choros para violão concebidos no Brasil e publicados por uma editora de grande prestígio e circulação no Brasil e na Argentina, assumindo, desde o subtítulo, o gênero urbano brasileiro que vinha se consolidando no Rio de Janeiro desde a segunda metade do século XIX até as primeiras décadas do XX. A título de exemplo, o Choros n. 1 e o Chorinho da Suíte Popular Brasileira, ambas peças de Heitor Villa-Lobos, datam respectivamente de 1920 e 1923, mas essa última obra "foi publicada pela primeira vez apenas em 1955, mais de 30 anos após a data de composição." (LIMA, 2017, p. 11); Joaquim 
Francisco dos Santos (1873-1935), o Quincas Laranjeiras, também tem um Choro n. 1, localizado pelos autores no acervo Jacob do Bandolim, atualmente abrigado no Museu da Imagem e do Som do Rio de Janeiro (MIS-RJ), mas que não apresenta data de composição e/ou cópia.

\section{O contexto dos raros choros para violão de personagens pioneiros}

Entre fins dos anos oitocentos e primeiras décadas dos novecentos, é muito provável que choros para violão abundassem entre violonistas cariocas (e mesmo de outros estados, com a circulação nacional que paulatinamente o gênero começou a adquirir desde que suas bases começaram a ser estabelecidas), mas grande parte deles não foi escrito, gravado, publicado e/ou teve seus manuscritos ou cópias preservados nos anos seguintes, um fato especialmente aplicável ao material exclusivo para violão. O caso de Colibri é uma exceção, um dos raros exemplos de peça do gênero escrita na década de 1910 e publicada na década de 1920 (por uma grande editora latino-americana) e ainda com o seu autor em vida, configurando-se, por isso, em um dos choros pioneiros para o instrumento no Brasil.

Um dos fatores decisivos para apenas uma parcela mínima deste repertório emergente ter nos alcançado é a constatação de que muitos dos violonistas praticantes do choro ou de outros gêneros populares não tinham o hábito de escrever suas obras em partituras, desenvolvendo idiomatismos instrumentais próprios, mas que majoritariamente eram aprendidos, desdobrados e disseminados através da oralidade e da prática oriunda do convívio musical direto.

As raízes do choro são comumente atribuídas à classe média urbana carioca da segunda metade do século XIX. O violão foi bastante requisitado na música popular nesse período, durante o qual o choro pode ser compreendido como uma maneira de interpretar gêneros populares europeus que se estabeleciam no Brasil. Nesse contexto, os conjuntos de pau e corda [flauta, cavaquinho e violão] foram essenciais para as bases constitutivas do choro com fulcro na tradição oral e performática (BORGES; VOLPE, 2020, p. 4).

Isso não quer dizer necessariamente que os/as violonistas brasileiros (ou radicados no Brasil) desconheciam o código, já que alguns deles detinham, sim, o conhecimento da escrita musical desde a primeira metade do século XIX, algo que se pode depreender dos inúmeros anúncios de jornais publicados em diferentes províncias do país a pontuar o quão o ensino do violão "por música" (com partitura) já era uma prática recorrente e paralela ao aprendizado "sem música" (de ouvido).

Joaquim de Santa Anna, faz Publico que todas aquellas pessoas que quizerem aprender a tocar violão Francez, ou viola de corda de arame, pela escalla Portugueza; pódem dirigir-se a rua do Espirito Santo N. 2, na entrada da Praça da Constituição; adverte-se que ensina-se por muzica, e também sem ser por muzica. (Diário do Rio de Janeiro, 1828, p. 3). 
No choro, contudo, a necessidade da escrita esbarrou em dois fatores específicos do gênero: primeiro, dentre as/os seus praticantes, prevalecia um número maior dos que não dominavam a escrita musical; além disso, os que aprenderam o código se inseriam em uma realidade na qual, muitas vezes, não havia a necessidade de se colocar o conteúdo em pauta, já que os procedimentos (especialmente os acompanhamentos e improvisos melódicos), em uma roda, eram usualmente feitos sem necessidade de preparação, através do treinamento e desenvolvimento auditivo dos/as praticantes (prática tão comum que gerou gírias no senso comum: na "orelhada" ou "de ouvido"). Ou seja, mesmo dentre os que podiam escrever os choros brasileiros pioneiros para violão, poucos deixaram registros.

Dentre os chorões do período, talvez o exemplo de Sátiro Bilhar seja o mais emblemático, reconhecido que fora por suas capacidades de improvisar diante de qualquer tema, fazendo com que o seu conteúdo transitasse entre gêneros, estilos, ambiências e espaços socioculturais diversos. Villa-Lobos, por exemplo, nutria tamanha admiração por esse jeito peculiar de executar as obras que escreveu a sua Bachianas Brasileiras no 1 "à maneira de Sátiro Bilhar". Ao comentar tal homenagem, Carvalho (1988, p. 54) sugere que João Pernambuco, Sátiro Bilhar e Donga são alguns dos "mestres de uma 'Escola' violonística autenticamente nossa, rica de matizes e de brasilidade, pesquisadores espontâneos de temática rítmica de nossas danças", sendo, portanto, "músicos intuitivos, que desconheciam a escrita musical".

Assim, para ter suas obras registradas em partitura, os violonistas que não possuíam o conhecimento do código precisavam eventualmente contar com a disposição e ajuda de quem o dominava. Nesse sentido, o papel de Melchior Cortez foi decisivo. Dono de uma sólida formação musical, o músico criou uma obra para violão solo que contempla originais, transcrições, arranjos e cópias manuscritas de peças de outros compositores, inclusive com publicações de algumas destas últimas, caso da valsa Gemidos d'Alma, de Josué de Barros (1888-1959), lançada pela editora Arthur Napoleão/ Casa Sampaio Araújo \& C ${ }^{\underline{a}}$, no Rio de Janeiro, com copyright datado em 1930. 


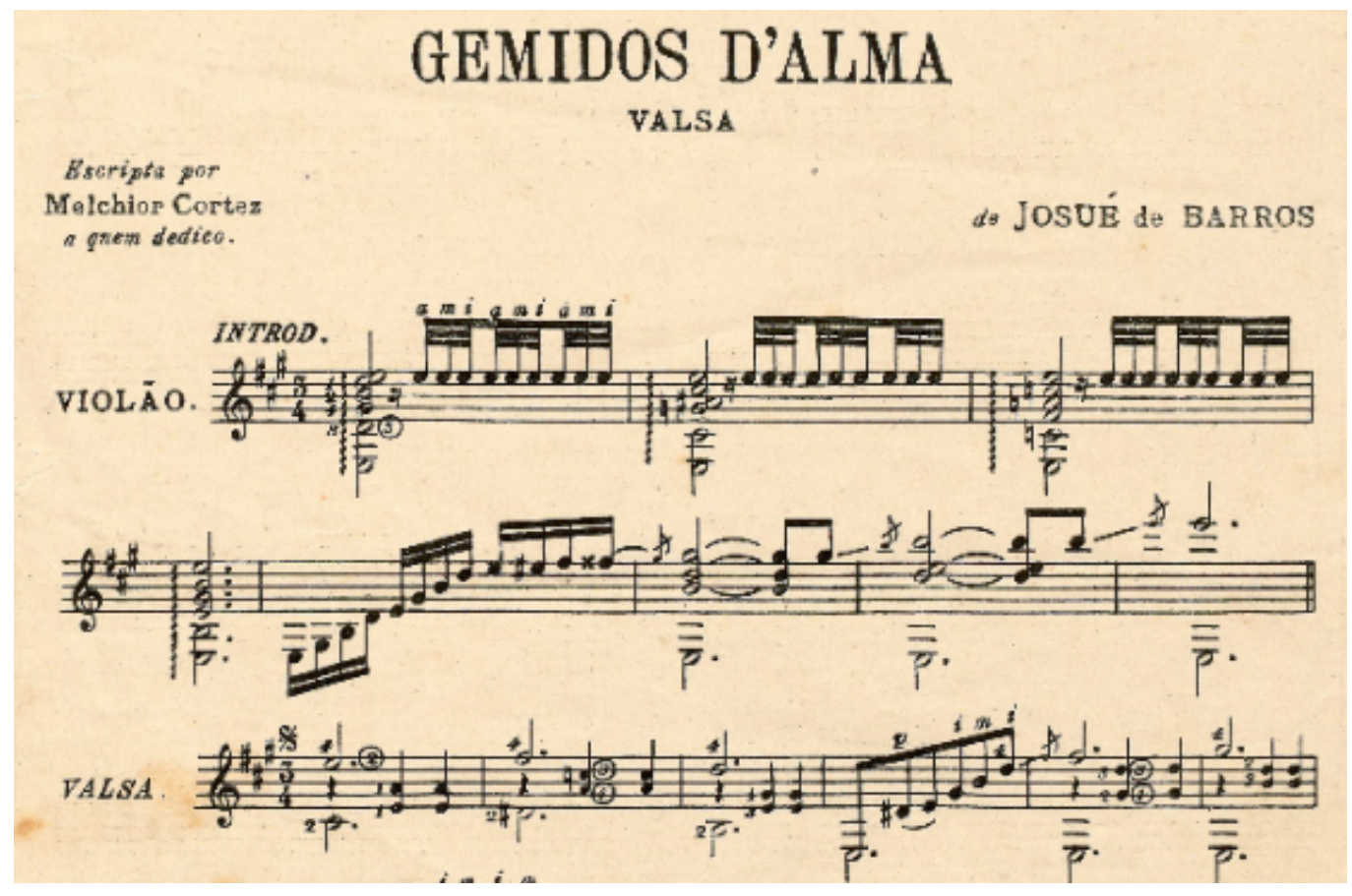

Fig.5: Cabeçalho e pautas iniciais de Gemidos D’Alma, de Josué de Barros. Fonte: Barros (1930).

Ao lado esquerdo do cabeçalho, há a constatação de que Melchior não somente foi o responsável pela escrita musical, mas também a quem a obra foi dedicada. Compositor, professor de violão e articulador cultural, Josué de Barros foi um violonista mais vinculado aos gêneros ditos populares e uma figura decisiva no emergente movimento radiofônico e fonográfico brasileiro, reconhecido, dentre tantas ações, por ter revelado a cantora Carmen Miranda (1909-1955), por ser um dos introdutores do violão elétrico no Brasil e por ter acompanhado ou feito parcerias com personagens da música brasileira como Radamés Gnattali (1906-1988) e Lamartine Babo (1904-1963). Já Melchior Cortez foi um artista que sempre teve o cuidado de projetar a sua carreira como um compositor e violonista vinculado à tradição da música de concerto, reiterando essa imagem pública em diversas publicações e entrevistas em jornais.

O cruzamento destes dois importantes personagens pioneiros do violão brasileiro - Melchior Cortez e Josué de Barros - configura-se em mais uma demonstração de que, apesar de muitas vezes estimulada pelos próprios agentes, as diversas tradições que compuseram a gênese do instrumento no país não apresentavam paredes muito altas. Pelo contrário, a genealogia embaralhada é um componente estrutural inescapável do violão no Brasil. Melchior é uma demonstração viva do fato: por um lado, defendia que a música clássica era a única "verdadeira e sã"; por outro, não deixou de publicar modinhas em coletâneas no início da carreira, de arranjar e veicular nos jornais canções populares famosas à época (tanto para solo quanto para canto com acompanhamento de violão) ${ }^{11}$, de ter uma rede de colegas profissionais, violonistas ou não, que não per-

11 Um exemplo é a canção A Mulher e o Trem, publicada em arranjo para voz e violão de Melchior Cortez e encontrada por nós em um recorte de jornal pertencente à Coleção Almirante/ MIS-RJ. 
tenciam à tradição estrita da música de concerto (como Josué de Barros e Gadanho), e de ter, ele próprio, escrito e publicado peças para violão solo (por grandes editoras brasileiras e argentinas) que dialogavam estreitamente com os gêneros da música popular urbana do Brasil e de outros países (como o fado português e temas populares espanhóis). Direta ou indiretamente, todas estas matrizes compuseram decisivamente o cabedal de referências do violonista que queria pública e exclusivamente ser vinculado à tradição "clássica", aquela da qual, segundo ele, advinha "a verdadeira música, a música sã, com base científica." (Diários de Notícias, 1933, p. 9).

Colibri, porém, desmonta a redoma e evidencia este contexto mais amplo, em que um violonista de formação "erudita" tem a sua produção decisivamente atravessada pelos gêneros chamados de "populares". E não se trata de uma mera apropriação dos caracteres de uma tradição em outra, ou seja, um aproveitamento e/ou "desenvolvimento" de uma suposta música elementar que resultará em outra mais "verdadeira" e "elevada", mas, antes, a aparência de um imbricamento estrutural que já não pode ter partes desvinculadas ou subjugadas como inferiores. Por mais que a suposição contrarie os discursos dos próprios personagens do período (como Villa-Lobos e Melchior Cortez), o fato é que mesmo a obra dos autores mais autodenominados ou identificados como "clássicos" é largamente permeada por matrizes culturais diversas que escapam à simplificação dicotômica "erudito vs popular".

Ao falarmos numa 'identidade transitiva do violão brasileiro' pretende-se elucidar dois aspectos que agiriam de forma dialógica: a necesssidade de complemente e a ação complementadora. Um exemplo: o violonista oriundo do perfil escolástico-concertista que incorpora o perfil do violão híbrido-transitivo tanto adquire as possibilidades/apropriações deste perfil quanto contribui - desde o seu perfil de origem - para expandir/adicionar outras mais. (LLANOS, 2018, p. 97)

Portanto, para o violão, o papel das tradições populares não parece ter sido subserviente ou coadjuvante, mas o de um componente estrutural. Isto se aplica, ao menos, na constituição essencial das práticas e dos repertórios que herdamos, sejam eles orais ou escritos, já que muitos dos espaços de poder e representatividade não eram (e ainda não são) ocupados de forma igualitária entre as tradições.

O que resulta disso, no caso de Cortez, é que o personagem considerado por articulistas da imprensa carioca como "um dos mais brilhantes professores de música" e um "digno representante do violão clássico" do período (Diário de Notícias, 1933, p. 9) será responsável não somente por compor aquele que foi um dos primeiros choros para violão publicados, mas também o músico a registrar em partitura parcelas da produção dos violonistas populares de seu tempo e/ou daqueles que não dominavam os códigos da escrita musical, como Josué de Barros e Francesco Rosa Gadanho. Foi justamente através de Cortez que este último teve registrada a sua única peça conhecida, o choro Caranguejo. 


\section{Francesco Rosa, o palhaço Gadanho: cançonetista e violonista de sucesso nos circos brasileiros}

Francesco Rosa foi um imigrante italiano que desembarcou no Brasil em 1872 e cujos dados biográficos são pouco sabidos, especialmente em relação às primeiras décadas de suas atividades em território brasileiro. Antes de nos debruçar sobre as parcas informações que resgatamos sobre ele na literatura disponível e em fontes hemerográficas, é importante ressaltar a heterogeneidade da imigração italiana que, neste período, desembarcava em território brasileiro ${ }^{12}$ :

Existiam tensões reais não só entre italianos de classes sociais diferentes, mas ainda entre os que provinham de regiões distintas, pois tinham dialetos, costumes, alimentação e mesmo gestos próprios [...]. E, no âmago de todos estes homens que tentaram fare l'America, cria-se um corte entre os que constituem apenas força de trabalho e os que os exploram. (CARELLI, 1985, p. 18).

Pobres, mas brancos ou "mulatos" (como no caso de Gadanho), estes imigrantes que representavam a força de trabalho passaram a dividir territórios e competir pelas formas de sobrevivência com a população de ex-escravizados. Esta convivência foi responsável pela "[...] possibilidade de trocas importantes, de um hibridismo cultural, mesmo que hierarquizada pelas condições socioeconômicas de cada grupo" (CASTRO, 2008, p. 69). É neste contexto que o músico e palhaço Gadanho, imigrante pobre do sul da Itália, vai dividir o picadeiro dos circos brasileiros com artistas igualmente pobres nascidos no Brasil. Desde fins do século XIX até a década de 1910, pelo menos, os jornais de diversos estados brasileiros registram que o artista integrou o elenco de importantes companhias circenses: Spinelli, Temperani, François, Clementino, Norte-Americano, atuando também em cafés-cantantes e restaurantes.

Além das serenatas, festas populares e alguns espaços urbanos (cafés cantantes, cafés concertos, teatros e revistas), tudo indica que um importante centro da difusão da música na virada do século, em diversas localidades do Brasil, tenha sido o circo. Os palhaços eram as suas principais atrações, quase sempre se apresentando com violão no centro do picadeiro. Cantando modinhas e contando piadas, eles foram os principais divulgadores das músicas e dos gêneros musicais do período. Tinhorão aponta que, no Rio de Janeiro, os palhaços cantores só tinham equivalência com os cantores vendedores de modinhas (2005, p. 168).

Não foi por acaso que os primeiros cantores brasileiros da nascente indústria fonográfica brasileira (1902) foram os palhaços que se acompanhavam ao instrumento: Baiano (Manuel Pedro dos Santos 1870-1944); Cadete (Manoel Evêncio da Costa Moreira 1874-1960); o próprio Eduardo das Neves (1874-1919) e Mário Pinheiro (c.1880-1923), sendo que este último é considerado o responsável por uma das primeiras gravações de

\footnotetext{
12 Nunca seria demais recordar que o fenômeno do estado italiano como unidade federativa era algo recente (1870). "As questões regionalistas, muito vivas ainda hoje naquele país, davam a tônica para as características que os diversos grupos oriundos da península itálica exibiram em solo brasileiro" (CASTRO, 2008, p. 59).
} 
violão solo realizada por um brasileiro $(1910)^{13}$. Aliás, algumas das coleções de modinhas anunciadas a partir de 1905 também tinham inspiração nesse repertório:

\section{Modinhas Brasileiras}

A mais bonita e a mais completa coleção de modinhas, lundus e poesias, do repertório dos populares trovadores Eduardo das Neves e Bahiano, encontra-se na Lyra Popular Brasileira, 2a edição, um volume de 338 páginas, com linda capa a cores. (O Commercio de São Paulo, 1905)
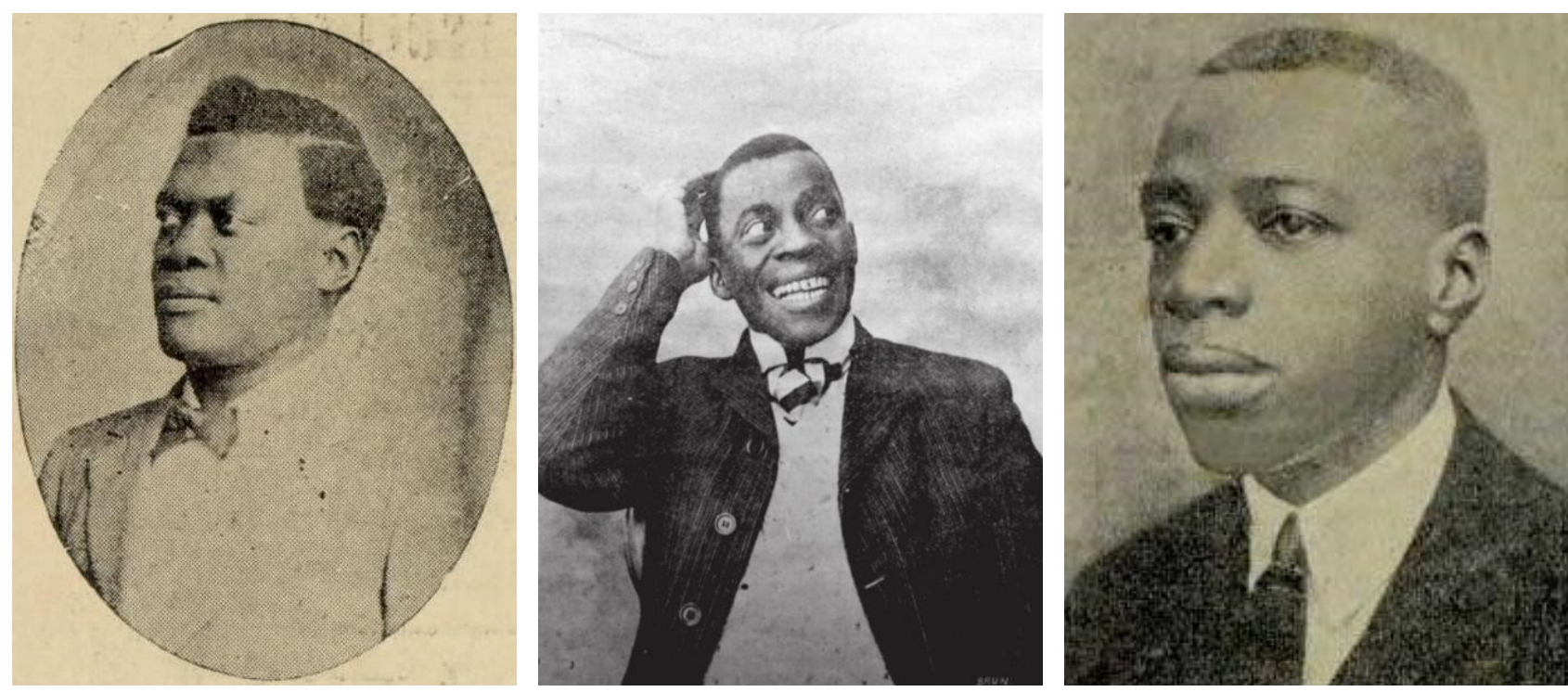

Fig.6, 7, 8: Da esquerda para a direita: Eduardo das Neves, Benjamin de Oliveira e Patrício Teixeira, músicos e palhaços negros que atuaram em circos empunhando o violão.

Fonte: LISBOA JÚNIOR (2016).

O caráter nômade e o grande poder de penetração social do circo permitiram uma difusão e circulação da música de tradição popular - antes do advento das gravações e das emissoras de rádio -, fato que ainda não mereceu a atenção detalhada por parte dos musicólogos $^{14}$. Os palhaços com seus violões viajavam divulgando um repertório que, quando passou a ser registrado em disco, já era conhecido do público. A circulação dos palhaços cantores-instrumentistas facilitava não somente a venda de discos, mas assegurava a conquista de novos públicos. Assim, conforme os circos transitavam, iam espraiando o repertório e ampliando o potencial público consumidor das gravações. É necessário lembrar que os intercâmbios entre os ritmos e gêneros musicais em decantação, com suas incorporações e transformações, estavam presentes nos diversos espaços urbanos em formação, e o circo passou a ser fundamental na difusão dessa produção.

13 Mário Pinheiro lançou um disco de solo de violão, o Victor 98.989, com a música Petita (matriz B-9306), segundo a Discography of American Historical Recordings, gravado em 06 jul. 1910, realizada em Nova lorque. Disponivel em: https://adp.library.ucsb.edu/index.php/matrix/detail/200009417/B-9306-Petita, acesso em 03 out. 2020. O pesquisador Sandor Buys indica que, ao lado da gravação de Petita realizada por Mário Pinheiro, outras duas peças para violão foram gravadas por volta de 1910: Jaci e Sertanejo, um solo de violão possivelmente gravado por João Pernambuco; e Rio-grandense, de $A$. Palmieri, em gravação do próprio autor. Disponível em: https://sandorbuys.wordpress.com/2016/05/05/o-primeiro-solo-de-violao-gravado-no-brasil/ Acesso em 08 maio 2021.

14 A pesquisadora Ermínia Silva abordou o assunto em suas pesquisas de mestrado e doutorado sobre a arte circense (SILVA, 1996; 2003). 
Eram tocados e dançados em festas particulares, festas religiosas e em lugares públicos de onde ficavam conhecidos dobrados, quadrilhas e fandangos. As apresentações musicais desenvolvidas pelos cômicos cantores e tocadores de violão, as cenas cômicas e as pantomimas iam se tornando cada vez mais os números principais dos espetáculos circenses, transformando aquele que os realizavam, assim como os que os produziam, em sucessos garantidos e premiados. (SILVA, 2003, p. 183)

O circo foi ainda um espaço privilegiado de profissionalização dos músicos. Eduardo das Neves foi proprietário de um circo em São Paulo e recrutou músicos como Roque Ricciardi, o Paraguassú, Américo Jacomino, o Canhoto, e Aníbal Augusto Sardinha, o Garoto. É a partir deste contexto mais amplo que o nome de Francesco Rosa desponta. Segundo Penteado, citando os diversos circos em atuação em São Paulo na primeira década do século XX, havia, no circo François, o palhaço Benjamim de Oliveira, "emérito violonista e cantor apreciável" ${ }^{15}$, além de outro palhaço, de nome Gadanho, que era um "ás do violão." (2003, p. 170).

Um ás do violão que acabou a sua carreira por volta da década de 1930, sem glamour (como a maioria de seus pares) e sobrevivendo no Rio de Janeiro como o músico que anunciava, cantando às mesas de um modesto estabelecimento de massas, o cardápio com a lista dos pratos do dia. Mais do que um retrato da luta pela sobrevivência enfrentada pelos músicos violonistas do período, Gadanho, de certa forma, representa a junção prática e simbólica de algumas das camadas que compuseram o caldeirão do violão brasileiro: um estrangeiro que desembarca em terras cariocas, passa a disputar espaços profissionais predominantemente ocupados por personagens negros, embrenhando-se dos cruzamentos entre danças europeias ainda em voga, tradições culturais afro-brasileiras e gêneros musicais emergentes. Em síntese, um imigrante pobre, do sul da Itália, que chega ao Brasil no início do século XX e passa a dividir mercado de trabatho com ex-escravizados e igualmente pobres, trabalhando como soldado e também em circos e restaurantes, absorvendo as trocas culturais que permitiram que, por volta da década de 1910, ele se tornasse o compositor de um dos primeiros choros para violão solo de que se tem notícia no Brasil.

\section{Caranguejo e Colibri: relação entre as peças e permeabilidades entre a polca e o choro}

Se resgatarmos o conteúdo da já mencionada nota de rodapé que consta na primeira página da edição de Colibri, é possível depreender duas informações decisivas:

- Inicialmente, que a peça de Cortez, além de funcionar para violão solo (conforme indica o subtítulo da publicação: "Choro para violão"), também poderia eventualmente ser tocada em duo com outro choro;

- Depois, a indicação de que se o choro Colibri foi composto em 1912 para ser tocado com o choro Caranguejo, provavelmente este último é ainda anterior, configu-

15 Ver mais sobre a história do palhaço Benjamin em: (SILVA, 2003). 
rando-se em mais uma obra do gênero que circulou a ponto de inspirar a pena de um dos violonistas "clássicos" mais reconhecidos do Rio de Janeiro nas primeiras décadas do século $X X$.

Até agora, não era possível dimensionar qual o grau de diálogo entre as duas obras, notadamente porque não existiam informações sobre cópias editadas ou manuscritas de Caranguejo, tampouco rastros do paradeiro de seu autor (cujo nome não é mencionado na edição de Colibri). O novelo começou a se desenrolar quando descobrimos uma versão manuscrita da obra no arquivo passivo (ainda não catalogado) da Coleção Ronoel Simões, pertencente ao acervo da Discoteca Oneyda Alvarenga, atualmente abrigada pelo Centro Cultural São Paulo (CCSP).

Um fato importante é a constatação de que o manuscrito tem a caligrafia musical de Melchior Cortez, mais um dado a corroborar a correspondência entre os choros. Embora Cortez não assine como copista o manuscrito de Caranguejo, foi possível identificar a sua caligrafia através da comparação direta com outra de suas cópias descoberta por nós, o seu arranjo para dois violões de Dores d'Alma, uma das mais famosas peças para violão solo de seu parceiro de duo, Joaquim Francisco dos Santos (1873-1935), o Quincas Laranjeiras.
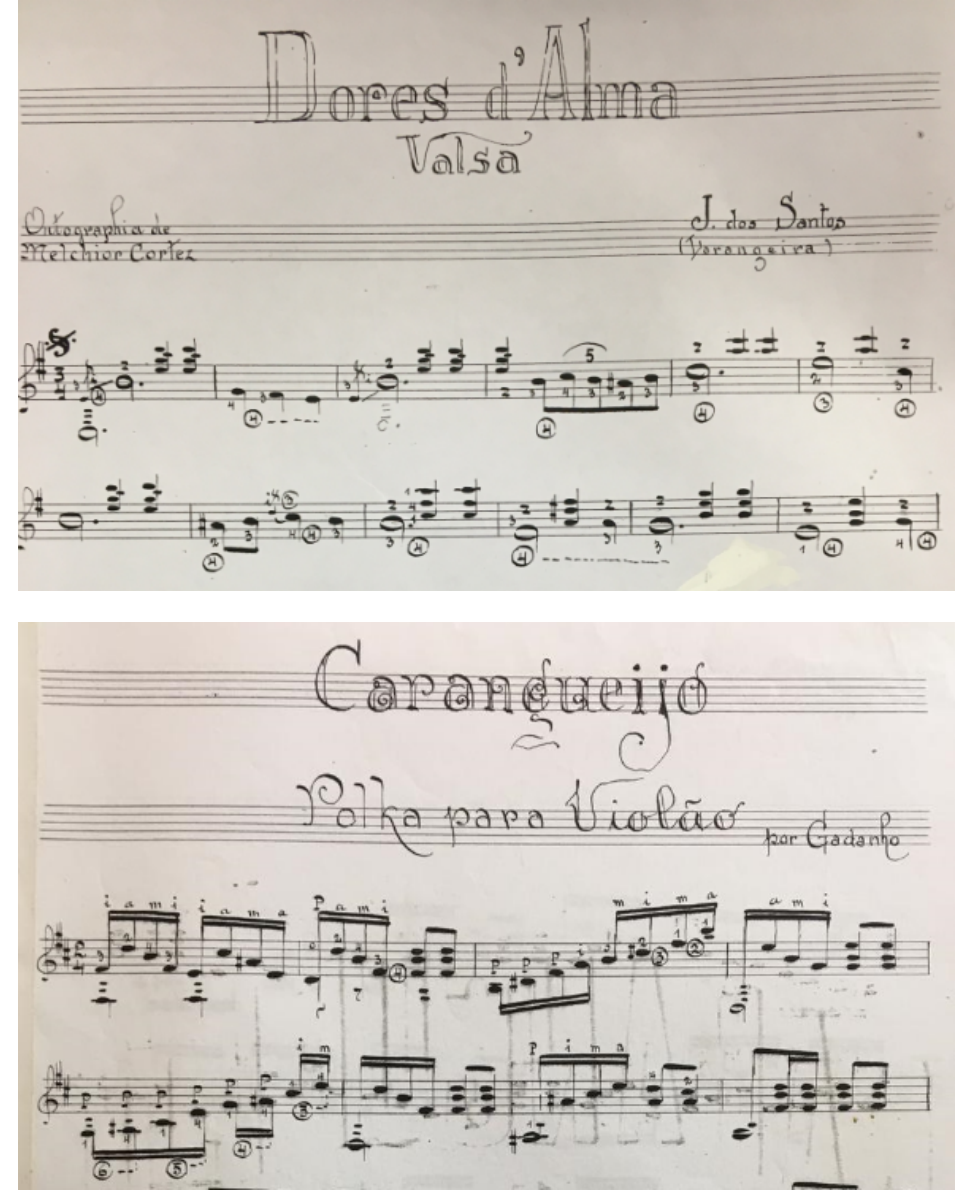

Fig. 9 e 10: Indicação de "ortografia" de Cortez no arranjo para dois violões de Dores d'Alma. Fonte: Coleção Ronoel Simões. 
Estruturalmente, tanto Colibri quanto Caranguejo são construídas em três seções, de 16 compassos cada, com a primeira seção em Si menor (tonalidade menor), a segunda em Ré maior (relativo), e a terceira (C) também em Si menor (retorno da tonalidade menor). A forma assumida nas duas obras é a do Rondó, ou seja, $A B A C A^{16}$, e os finais de cada uma das seções são marcados por cadências características e recorrentes. À exceção do campo harmônico da seção $C$ (no qual teoricamente se esperaria o tom homônimo), tais componentes estruturais estão de acordo com o que Borges e Volpe (2020, p. 8) identificam como alguns dos elementos típicos do Choro Tradicional (CT). ${ }^{17}$

Porém, há uma dubiedade terminológica em relação ao gênero musical de Caranguejo: no manuscrito assinado por Cortez, a peça é descrita como uma "Polka para Violão", diferentemente do que o próprio Cortez indica na versão de Colibri publicada pela Casa Romero y Fernandez, na qual classifica as duas peças de "choro". Desde meados do século XIX até as décadas iniciais do XX, foi comum (para além do violão) esta paridade nominal entre muitos dos termos que originalmente identificavam danças europeias e os gêneros musicais que eclodiam no Brasil, uma vez que, musicalmente, tais atravessamentos foram decisivos para a compleição dos próprios gêneros musicais brasileiros. "Não é exagero afirmar que o material musical que deu origem ao Choro está intimamente ligado aos enfrentamentos culturais relativos aos encontros musicais entre as danças europeias e as danças africanas." (RAMOS, 2016, p. 94).

Na segunda metade do século XIX, as práticas improvisatórias da música popular conviveram com a música escrita no Brasil, com destaque para as publicações de partituras para piano. As publicações atraíam pianistas amadores, consumidores ávidos por polcas, tangos, valsas, lundus, mazurcas e schottisches (BORGES, 2019, p. 3). Esses gêneros musicais, compreendidos como danças do choro (BRAGA, 2004), foram apropriados ao longo do século XX por intermédio de arranjos dos regionais de choro. (BORGES; VOLPE, 2020, p. 4)

No repertório brasileiro para violão escrito até as primeiras décadas do século $X X$, talvez não haja exemplo musical e terminológico mais conhecido e representativo deste espaço imbricado do que a Suíte Popular Brasileira, de Heitor Villa-Lobos (18871959). Desde os manuscritos compostos ainda nos decênios iniciais dos novecentos, 0 conteúdo e o título de tais peças expressam como havia uma camada cinzenta entre algumas das danças europeias e o emergente gênero musical urbano do Rio de Janeiro: Mazurka-Choro, Schottish-Choro, Valsa-Choro, Gavotta-Choro e Chorinho.

\footnotetext{
16 Segundo Palópoli, o modelo formal do choro tradicional tido como padrão faz referência "à pequena forma rondó, oriunda da polca e amplamente utilizada por compositores brasileiros." (2018, p. 26-27, grifo nosso).

17 "Primeiramente, é comum observar a modulação típica no CT [Choro Tradicional], cuja estrutura segue a forma rondó ABACA: A (tonalidade maior), B (relativo) e C (subdominante) ou A (tonalidade menor), B (relativo) e C (homônimo). No fim dessas seções, existem cadências recorrentes (similares ao turnaround do jazz) as quais podem ser entendidas como volteio harmônico tanto no CT quanto no CNT [Choro Não Tradicional] (BORGES, 2008b)." (BORGES; VOLPE, 2020, p. 8).
} 


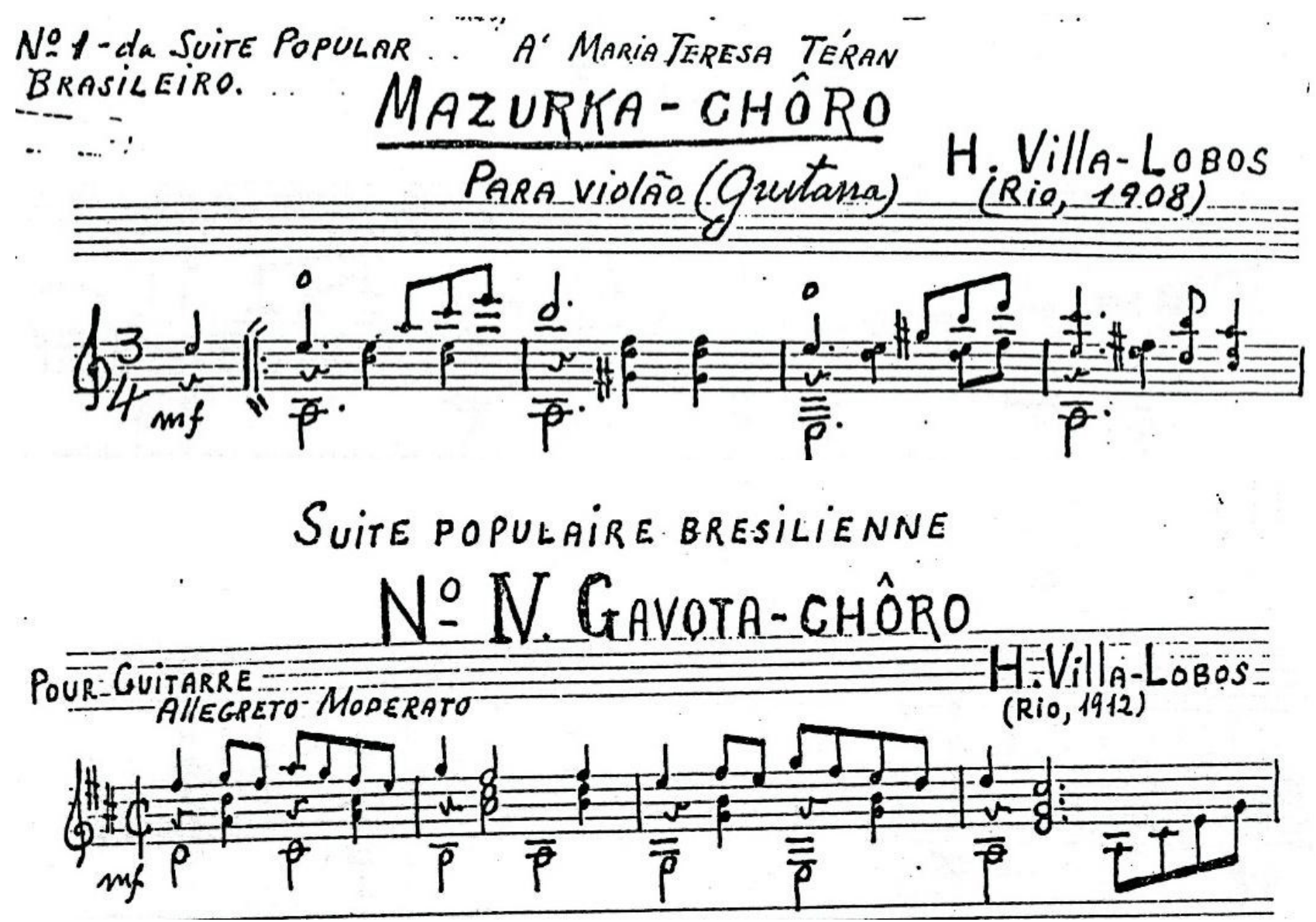

Fig.11 e 12: Cópia dos manuscritos da Mazurca-Choro e Gavota-Choro. Fonte: Museu Villa-Lobos/ MVL - P.202.1.3. e P.202.1.8.

No caso específico da polca, o atravessamento parece ter sido ainda mais constitutivo, tornando-se, para os chorões, a mais decisiva dentre as "danças do choro", ou seja, o objeto de uma prática musical na qual as danças europeias eram executadas "em um estilo interpretativo nacionalizado, por isso a vinculação à palavra 'choro'." (PALÓPOLI, 2018, p. 34). Ao comentar o repertório dos chorões pioneiros no dicionário Grove, o musicólogo franco-brasileiro Gerard Béhague (1937-2005) ratifica a perspectiva ao sugerir que "nenhuma música especial foi composta para os choros naquela época, mas designações como polca-choro e valsa-choro indicam a nacionalização de danças europeias no Brasil". (BÉHAGUE apud PALÓPOLI, 2018, p. 34). Cazes engrossa o coro ao afirmar que a "maneira chorosa de frasear", ou seja, um determinado estilo de interpretação, "teria gerado o termo chorão, que designava o músico que 'amolecia' as polcas." (2005, p. 17).

No item 1.3 de sua tese de doutorado - Polca chorosa e brasilidade -, Palópoli aponta para o fato de que a polca foi o gênero que mais se popularizou dentre as danças europeias que se fixaram no Brasil a partir da chegada da família real portuguesa (1808), sugerindo que a bibliografia de referência "leva-nos à certeza de que a execução instrumental em território brasileiro se diferia daquela praticada na Europa." (2018, p. 42-43). Para embasar a afirmação, a autora suscita argumentos expostos nos livros de Pinto (2014 [1936]), Lira (1938), Vas- 
concelos (1984), Cazes (2005 [1998]), Sève (2016), além de uma passagem de Machado que se mostra particularmente importante para este estudo: "uma polca interpretada de modo sincopado poderia ser chamada de choro." (2007, p. 30).

Esta perspectiva foi corroborada por trabalhos musicológicos de referência publicados ainda na primeira metade do século XX. Em 1942, por exemplo, o musicólogo Renato de Almeida já indicava que "as valsas, as quadrilhas, os schottisches e as polcas, principalmente as polcas, se abrasileiraram", acrescendo que nós, brasileiros (as), "fizemos a nossa polca, o nosso tango, o nosso maxixe." (1942, p. 154, grifo nosso).

Dentro deste contexto, podemos sugerir que no hiato entre a fusão das danças europeias com um estilo interpretativo "chorado" e marcado pela "brasilidade" (o que ocorreu desde meados do século XIX) até a consolidação do choro como gênero musical nas décadas iniciais do século $X X^{18}$, houve um período de imprecisões conceituais e terminológicas que podem ser sintetizadas no seguinte depoimento de Alfredo da Rocha Vianna Filho (1897-1973), o Pixinguinha: “É preciso esclarecer que naquela época não havia choro, e sim música de choro, música que fazia chorar. Nesse aspecto, polca também podia ser choro." (apud CARVALHO, 1986 [1968], p. 176).

É precisamente esta permeabilidade musical e terminológica entre a polca e o choro que justifica as diferentes designações que Melchior Cortez empregou para uma mesma peça. O choro Colibri, de 1912, foi publicado pela Casa Romero y Fernandez na década de 1920. Na edição, em nota de rodapé que consta na primeira página da partitura, Cortez indica que a peça fora concebida para ser tocada com outro choro, Caranguejo.

NOTA: Esta muzica foi feita em 1912 para tocar com o chôro intitulado "CARANGUEIJO.

Fig.13: Nota de rodapé na edição de Colibri da Casa Romero y Fernandez.

Fonte: Cortez ([s.d.]).

Entretanto, no manuscrito de Caranguejo encontrado na Coleção Ronoel Simões e que apresenta caligrafia musical do próprio Cortez, a peça passa a ser descrita como "polca para violão". O documento não é datado, o que não nos permite saber se a cópia é anterior ou posterior à data de composição de Colibri (1912).

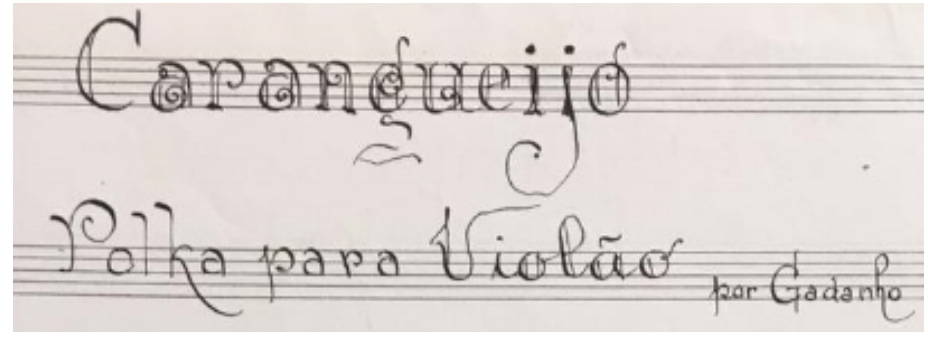

Fig.14: Cabeçalho de Caranguejo, de Gadanho, em cópia manuscrita de Cortez.

Fonte: Coleção Ronoel Simões.

18 (PALÓPOLI, 2018, p. 44). Para embasar a inferência, a pesquisadora cita Cazes (2005 [1998], p. 17); Severiano (2008, p. 35); e Carrilho (In: SĖVE; SOUZA; SILVA, 2009, p. 37). 
Costa destaca que "a partir deste amálgama, foram criadas condições para a conversão de um estilo de se tocar em gênero musical - o choro -, principalmente a partir de meados do século XIX" (2020, p. 2-3), indicando ainda que as variações da polca representaram "um dos mais importantes pilares para a constituição do choro enquanto gênero musical autônomo." (2020, p. 6). Em função disso, durante o período de consolidação desse processo (de meados da segunda metade do século XIX até as primeiras décadas do XX), polca e choro foram muitas vezes designações intercambiáveis, inclusive gerando nomenclaturas combinadas: "polca-choro".

As trocas entre as práticas musicais locais e aquelas que nos chegaram oriundas de diversas localidades (sobretudo europeias e africanas ${ }^{19}$ ) não passaram incólumes ao repertório exclusivo do violão, que absorveu os atravessamentos musicais e terminológicos que marcaram o período. Composta por volta de 1912 (provavelmente antes dessa data), Caranguejo é um registro que reitera a hipótese, ocupando uma zona movediça que, naquele momento, poderia situá-la quase que indistintamente entre a polca, a polca brasileira, a polca-choro ou simplesmente o choro. Abaixo, como ilustração, reproduzimos o padrão rítmico do que se convencionou chamar de polca brasileira, bem como duas de suas variantes, ambas levadas ${ }^{20}$ recorrentes no repertório tradicional dos chorões:

\footnotetext{
19 Citando Sève (2016b), Costa indica que "tal forma peculiar de lidar com as informações musicais estrangeiras foi perpetuada e influenciou a produção de músicos referidos na literatura como pertencentes a uma geração pioneira de chorões: Joaquim Callado, Viriato Figueira e Chiquinha Gonzaga, e, um pouco mais tarde, Ernesto Narareth e Anacleto de Medeiros, para citar somente alguns dentre os mais expressivos exemplos entre os referidos fundadores. Estes, a despeito das particularidades de suas vivências musicais, não se furtavam a explorar em suas composições e performances o uso de melodias sobre acompanhamentos ritmicamente sincopados, sob possível influência da música de origem africana." (2020, p. 3). Dialogando com a bibliografia, contudo, o próprio Costa adverte que é preciso fazer tais remissões com cuidado: "Carlos Sandroni (2012: 24-28) destaca a escassez de comprovaç̃̃es documentais da associação entre a síncope brasileira e a música de origem africana na literatura sobre o tema. 0 autor ressalta, por outro lado, ser legítima a suposição de que as características rítmicas que distinguem a música brasileira façam parte de uma herança musical trazida da África negra. Cacá Machado, um dos biógrafos de Ernesto Nazareth, destaca a recorrência na historiografia da ideia de que "a acentuação do tempo fraco do compasso dos gêneros dançantes europeus, cuja denominação técnica é a síncopa, foi invariavelmente atribuída à influência da cultura musical negra ou africana durante o processo de colonização" (2007: 108), referindo-se às ex-colônias europeias onde negros foram escravizados, a exemplo do Brasil. Ele acrescenta, no entanto, que tal narrativa foi insuflada por ter encontrado no desejo de caracterização de uma identidade cultural nacional, ostentado por alguns setores da sociedade brasileira, um grande aliado". (2020, p. 11).
}

20 "Termo do jargão musical usado para designar um tipo de fórmula essencialmente rítmica, tocado em especial pela bateria e/ou pelo baixo, que define claramente o estilo do arranjo." (ALMADA, 2000, p. 97). 


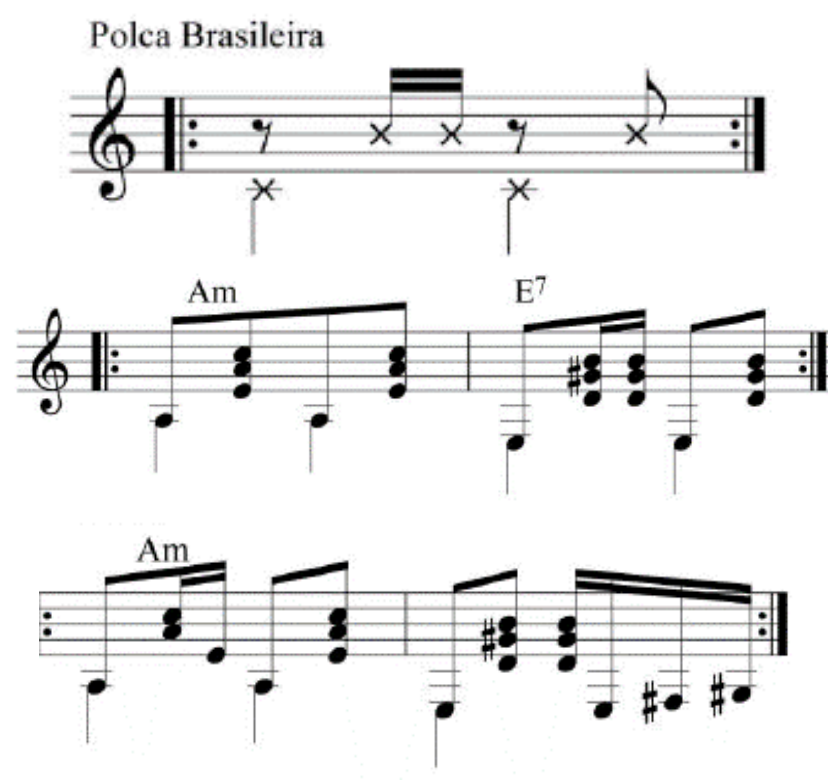

Fig.15, 16, 17: Padrão rítmico e duas variantes da polca brasileira.

Fonte: Pauletti (2015, p. 8).

Para nós, o ponto chave reside na presença maciça desses padrões tanto na construção de Colibri quanto na de Caranguejo, em uma sugestão de que ambas as obras refletiam a amálgama musical e terminológica que alcançou parte do repertório brasileiro para violão do período. Na gênese, as peças ocupam um espaço cinzento que, especialmente naquele momento, abrigava "os diversos gêneros musicais do universo do Choro" (PALÓPOLI, 2018, p. 28) ${ }^{21}$. E os subtítulos divergentes que Melchior Cortez emprega para Caranguejo, em ocasiões distintas, corroboram a inferência.

É necessário destacar que Caranguejo, por ter a posição de solista quando tocada em duo, não sustenta integralmente os padrões rítmicos de acompanhamento ao longo das três seções. Em Colibri, no entanto, tais procedimentos são fios condutores do enredo musical quase que ininterruptamente. Em ambas as peças, as referências à polca brasileira podem ser notadas ora de forma explícita e ora mais sutilmente, através das diversas combinações possíveis entre as variantes que elencamos. A remissão mais contundente se encontra justamente nos finais das seções, quando acordes repetidos em blocos reproduzem o padrão rítmico do gênero (eventualmente com pequenas variantes), tal qual ocorre em diversas passagens:

21 A própria Palópoli $(2018$, p. 49) apresenta uma ilustração com as possíveis levadas rítmicas de alguns dos gêneros musicais que fazem parte do Choro (tomado como manifestação cultural mais ampla), incluindo, dentre eles, a polca, a valsa, o maxixe, a schottisch, o tango brasileiro e o próprio choro (como gênero musical). 


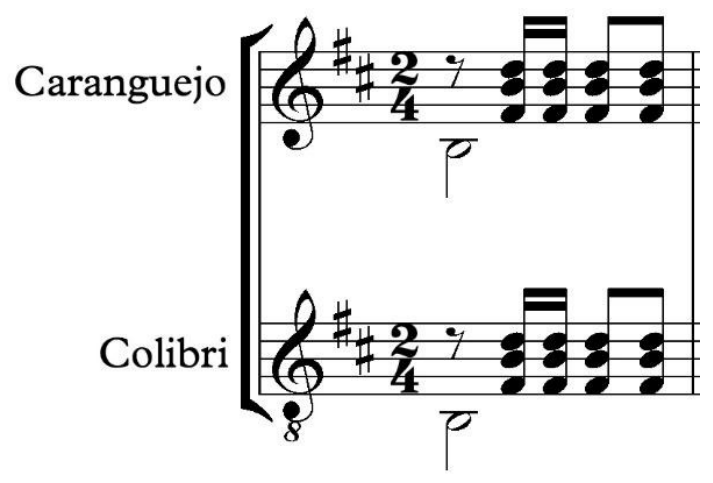

Fig.18: Fim da seção A de Caranguejo e Colibri.

Fonte: Elaboração dos autores (a).

Observe-se que o padrão rítmico não é a única convergência, já que se trata de um trecho literalmente igual nas duas peças (na tonalidade, harmonia e escolha das alturas, por exemplo), mais um fator a ratificar a correspondência entre elas. A simetria ocorre em finais de período (quando os temas são reexpostos) e no encerramento de cada uma das seções ( $A, B$ e C), momentos marcantes de confluência no conteúdo musical das obras. Em alguns casos, como no fim da seção $B$ (compasso 32), há a substituição da articulação da última colcheia do padrão por uma pausa. Nitidamente, Cortez (que compôs Colibri inspirado em Caranguejo) incorporou a escolha de Gadanho para manter os violões em uníssono:

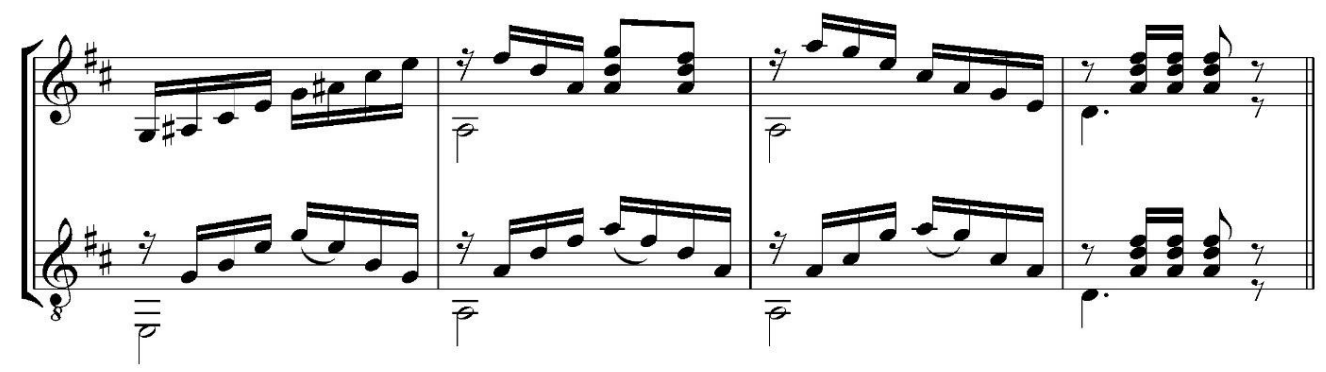

Fig.19: Fim da seção B de Caranguejo e Colibri.

Fonte: Elaboração dos autores (a).

Apesar das duas peças também funcionarem como obras para violão solo e suas performances isoladas serem perfeitamente plausíveis, já indicamos como ambas preservam padrões característicos de acompanhamento, havendo uma expressa complementaridade entre elas. Tal perspectiva nos levou a realizar uma edição prática das obras em duo, baseada nas fontes que suscitamos, e motivada especialmente pelo fato de que, ao tocar as peças conjuntamente, constatamos uma orgânica confluência de seus conteúdos musicais. 


\section{Caranguejo e Colibri em edição para duo de violões}

As fontes que utilizamos para realizar a edição conjunta foram as seguintes:

- Colibri: edição da Casa Romero y Fernandez, na Argentina, que não contém data de publicação, mas indica 1912 como o ano de composição da peça em uma nota de rodapé ao fim da primeira página da partitura. Além dessa, a editora argentina publicou diversas peças de Melchior Cortez e o violonista chegou a oferecer alguns de seus trabalhos aos proprietários do estabelecimento, com os quais teve contatos presenciais e por cartas, indicativos de que a edição de Colibri se trata de uma versão revisada e avalizada pelo compositor.

- Caranguejo: manuscrito com a caligrafia de Melchior Cortez encontrado no arquivo passivo da Coleção Ronoel Simões.

Estas fontes foram revisadas e digitadas por Humberto Amorim e Jefferson Motta e editoradas em versão para duo por Ivan Paschoito, a partir da aprovação de sua publicação dentro da "Coleção Humberto Amorim - Partituras raras para violão", da editora Legato. Como já observamos, as correspondências de tonalidade, fórmula de compasso, forma musical, número de compassos das seções e padrões rítmicos, melódicos, harmônicos e motívicos são, somados, fatores que não deixam dúvidas sobre a paridade das obras. Por isso, as poucas divergências que existem entre a edição publicada de Colibri e a versão manuscrita de Caranguejo se justificam mais por prováveis lacunas de escrita nesta última (que não passou, como a primeira, por um crivo editorial) do que por diferenças estruturais. Um exemplo está na comparação entre as seções $C$ das peças. Em Colibri, o fim do trecho é indicado com ritornello e notação de Casas 1 e 2:

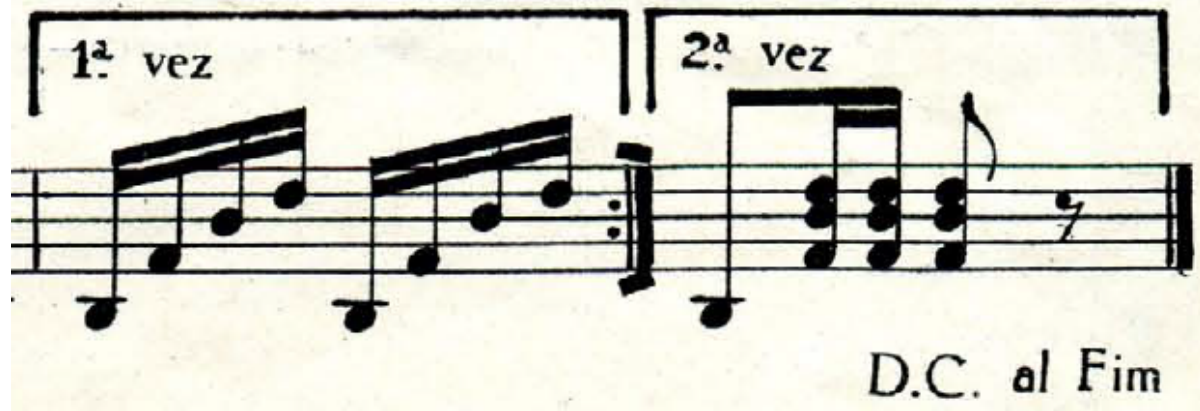

Fig.20: Fim da Seção C de Colibri. Fonte: Cortez ([s.d.])

Já em Caranguejo não há indicação de ritornello ou Casas 1 e 2 no fim da seção, o que poderia indicar a não repetição do trecho. Contudo, o início da própria seção apresenta uma barra dupla de repetição, sugerindo que a ausência de seu correspondente no último compasso do trecho se trata provavelmente de um lapso do copista. 


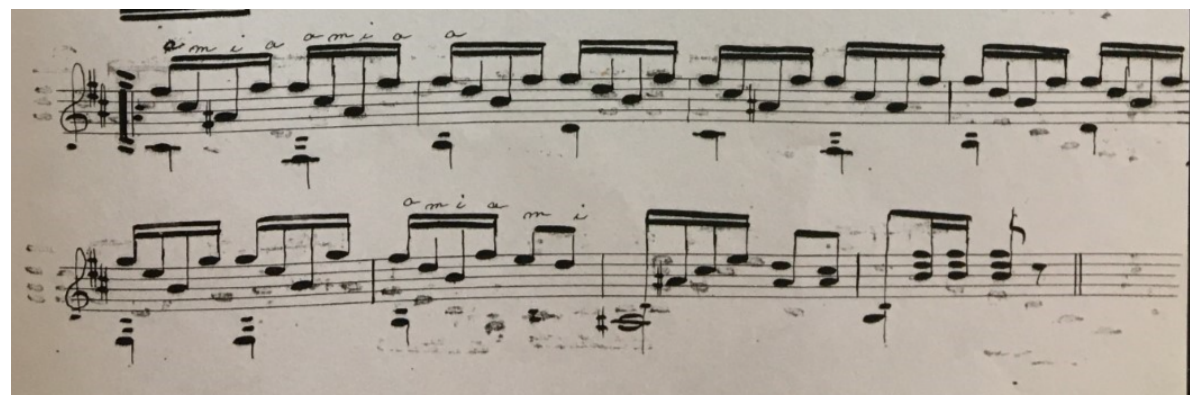

Fig.21: Seção C de Caranguejo. Fonte: Coleção Ronoel Simões.

Em relação ao conteúdo musical, houve apenas uma alteração de nota. No compasso 18 de Colibri, consta originalmente um Dó\# na cabeça do primeiro tempo, enquanto no mesmo compasso de Caranguejo irrompe um Ré, ocasionando um choque de segunda menor na passagem. Como a harmonia nitidamente articula um acorde de Ré maior, provavelmente houve um erro gráfico nas linhas suplementares inferiores quando Colibri foi editada pela Romero y Fernandez.
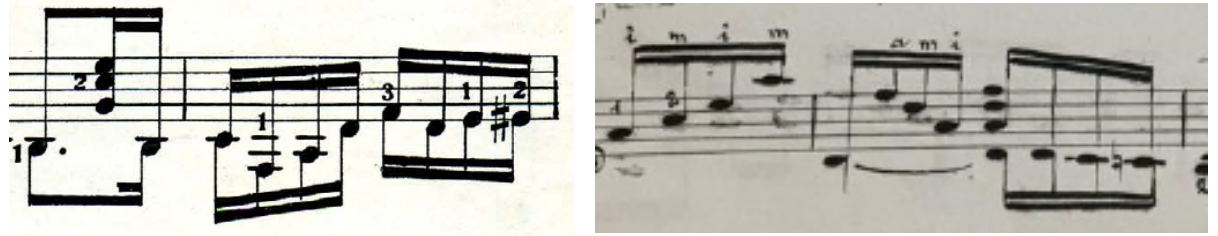

Fig.22 e 23: Compassos 18 de Colibri e Caranguejo: choque de $2^{a}$ menor na cabeça do primeiro tempo. Fontes: Cortez ([s.d.]) e Coleção Ronoel Simões (ms. de Caranguejo).

A solução encontrada foi substituir, em Colibri, o Dó\# por Lá, mantendo o encaminhamento do baixo em graus conjuntos e substituindo a nota original por uma que consta na tríade do acorde de Ré maior:

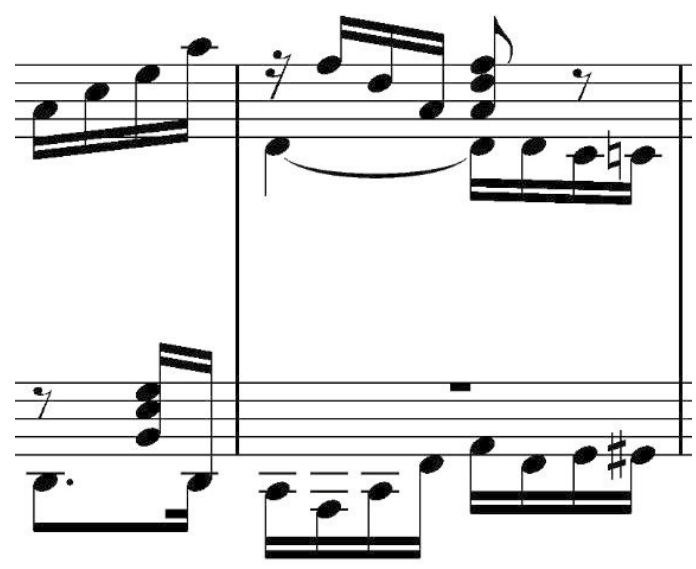

Fig.24: Compasso 18 com a substituição do Dó\# por Lá no baixo do segundo violão. Fonte: Elaboração dos autores (a). 
Este foi o único caso do gênero. Todas as demais intervenções se deram no âmbito de estabelecer critérios editoriais que pudessem eventualmente organizar melhor o emprego das hastes, da escrita polifônica, das durações, dos ritmos, do uso de pestanas, além de evitar notas duplicadas desnecessariamente e adaptar processos tipográficos antigos aos padrões vigentes na atualidade (GOULD, 2011).

\section{A escrita musical para violão: uma introdução}

O ato de fixar uma música no papel é de grande responsabilidade, principalmente quando não se é o autor da obra em questão, ocasião em que damos forma a algo que não concebemos. Ao contrário da música executada, que desaparece no ar depois do acorde final, a música materializada no papel é praticamente eterna. O mesmo acontece com o erro, durante uma audição será esquecido ao final, já um erro na partitura pode se perpetuar e se multiplicar em futuras reedições e gravações. Há exemplos concretos disso, tanto na música popular quanto na erudita. O primeiro registro escrito de uma obra musical de certa forma pode definir muito do que acontecerá com ela no futuro.

A música para violão é tradicionalmente escrita numa única clave, a de sol, uma oitava acima da nota real. Talvez inspirada na escrita para violino, essa prática se iniciou em meados do século XVIII. Até aí estão de acordo autores italianos e espanhóis, como Mario Dell'Ara (1988, p. 67) e Emílio Pujol (1991 [1956], p. 67). Cada um deles, porém, defende o seu país como tendo sido o berço desse modelo.

Essa prática de escrita, cristalizada como está, acabou por se tornar limitadora, considerando as possibilidades do instrumento: sua tessitura, polifonia e o desenvolvimento da técnica. A música para violão seria mais clara e precisamente expressa num sistema amplo de escrita, envolvendo as claves de Fá e Sol, pelo menos. Ou, idealmente, a de Dó também. Isso permitiria a chamada notação natural para o instrumento, onde até quatro vozes podem ser bem acomodadas. Obras originais complexas, como New York Rush, de Enrique Ubieta (1979) ou os arranjos polifônicos de Carlos Barbosa-Lima ou Roland Dyens teriam muito mais clareza na notação natural.

Mas a escrita em clave única está consagrada. Uma tradição de mais de dois séculos, um sistema de ensino consolidado e um gigantesco histórico de partituras publicadas validaram a prática. Propostas teóricas, como a do livro A troca da clave de Leonardo Boccia (1997), não causaram impacto. Raríssimas edições que fugiram a esse padrão - Fernando Sor (1814) ${ }^{22}$, Scarlatti / Sérgio Abreu (1987)23, Villa-Lobos / Roland Dyens (1992)24 - o fizeram para resolver problemas específicos e não para propor um novo sistema.

\footnotetext{
22 Trata-se da Fantasia op. 7, com 1a edição publicada em Paris, em 1814, pela editora de Jean Antoine Meissonier (1783-1857). Esta primeira edição é dedicada ao compositor francês de ascendência austríaca Ignace Joseph Pleyel (1757-1831), sendo escrita e publicada originalmente em dois pentagramas que se alternam por três claves (Sol, Dó e Fá). 0 editor, A. Meissonnier. editaria novamente a peça entre 1817-1822, porém já guiado pelos parâmetros da escrita consagrada em clave de sol, oitava abaixo. Em 1987, Brian Jeffery a incluiu no primeiro volume (dos nove) da coleção: Fernando Sor: the complete works for guitar in fac-símiles of the original editions (1987), em edição com notas e comentários.

23 Referência à versão de Sérgio Abreu (1948) para a Sonata K. 87-L. 33, de Domenico Scarlatti (1685-1757), publicada pela Ricordi em 1987 e cuja transcrição foi escrita em duas claves de sol.

24 Publicado em Paris pela Henry Lemoine, o arranjo de Roland Dyens (1955-2016) para a Ária da Bachianas Brasileiras n 5, de Villa-Lobos, foi escrito em dois pentagramas, nas claves de Sol e Fá, tal qual é comum na escrita do piano.
} 
O método tradicional de escrita traz algumas desvantagens:

- Dificuldade em acomodar as vozes, o que é resolvido limitando-se o número delas a duas ou três ou por meio do desalinhamento das notas de acordes ou arpejos para evitar sua superposição e consequente dificuldade de leitura.

- Excesso de linhas suplementares, tanto no grave quanto no agudo, especialmente em afinações com a sexta em Ré ou Dó. Num sistema com as claves de Fá e Sol, teríamos apenas uma linha suplementar, tanto no grave quanto no agudo.

- Espaço limitado para a colocação do dedilhado: cordas, mão esquerda, mão direita, pestanas, pelo menos.

- Como consequência natural da soma desses itens, o resultado é uma partitura, em geral, bastante poluída visualmente.

- Limitação na formação do músico violonista, treinado a ler e praticar em apenas uma clave.

\section{Critérios para uma nova edição de Colibri/Caranguejo}

Colibri foi impressa pela editora argentina Romero y Fernandez no início do século XX. Uma obra assim, escrita para violão pelo próprio autor, violonista, e impressa por editora profissional, tende a ser uma condição muito definidora da obra, que pode conferir a essa versão um certo status de definitiva e, talvez, até desencorajar futuros revisores a promover possíveis melhorias. Porém, considerando as questões a seguir, alguns de seus aspectos editoriais podem ser eventualmente atualizados, considerados os parâmetros vigentes de grafia musical/editorial, após o atravessamento de um século desde a sua publicação:

- A partitura foi gravada, como se dizia na época, pelo sistema de placas de chumbo. Sistema esse onde literalmente se entalhava a obra musical numa placa fina de chumbo com o auxílio de punções e estiletes. $O$ produto final resultava excelente, mas o processo, muito trabalhoso e complexo, não permitia correções com facilidade.

- A escrita para violão, nesses cem anos, foi se aperfeiçoando e adotando novas práticas, sempre visando à precisão e clareza.

- O surgimento dos modernos softwares de editoração musical - que incorporaram as práticas estabelecidas pelos copistas ao longo dos séculos - facilitaram enormemente o trabalho de typesetting musical, permitindo obter resultados melhores e mais precisos.

São razões que justificam uma intervenção um pouco mais ousada do editor, sempre, naturalmente, no sentido de se obter uma escrita que seja, ou pelo menos pareça ser, mais representativa da obra. No caso específico de Colibri e Caranguejo, cumpre tecer algumas considerações: 
- Já na comparação entre os primeiros compassos das obras, por exemplo, podemos identificar algumas das abordagens que realizamos para que o diálogo entre os dois instrumentos (que em muitos momentos parecem estar em um jogo de pergunta e resposta) resultasse ainda mais orgânico.
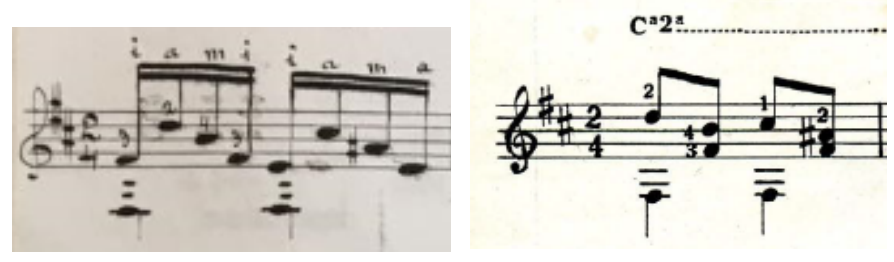

Fig.25 e 26: Primeiro compasso de Caranguejo e Colibri.

Fonte: Cortez ([s.d.]) e Coleção Ronoel Simões (ms. de Caranguejo).

Note-se que logo no primeiro compasso, o Fá sustenido grave da 6ํㅜ corda é articulado em ambas as peças. Entretanto, com a inclusão de um $2 \circ$ violão assumindo expressamente o papel de acompanhante, julgamos que a integração entre as partes poderia fluir melhor se $\circ 1$ 이이ão não repetisse as notas mais graves já contidas na cabeça dos tempos do $2^{\circ}$ violão. Através da inclusão de parêntesis para destacá-las, o resultado de nossa edição abre a possibilidade que as notas graves do violão solista sejam

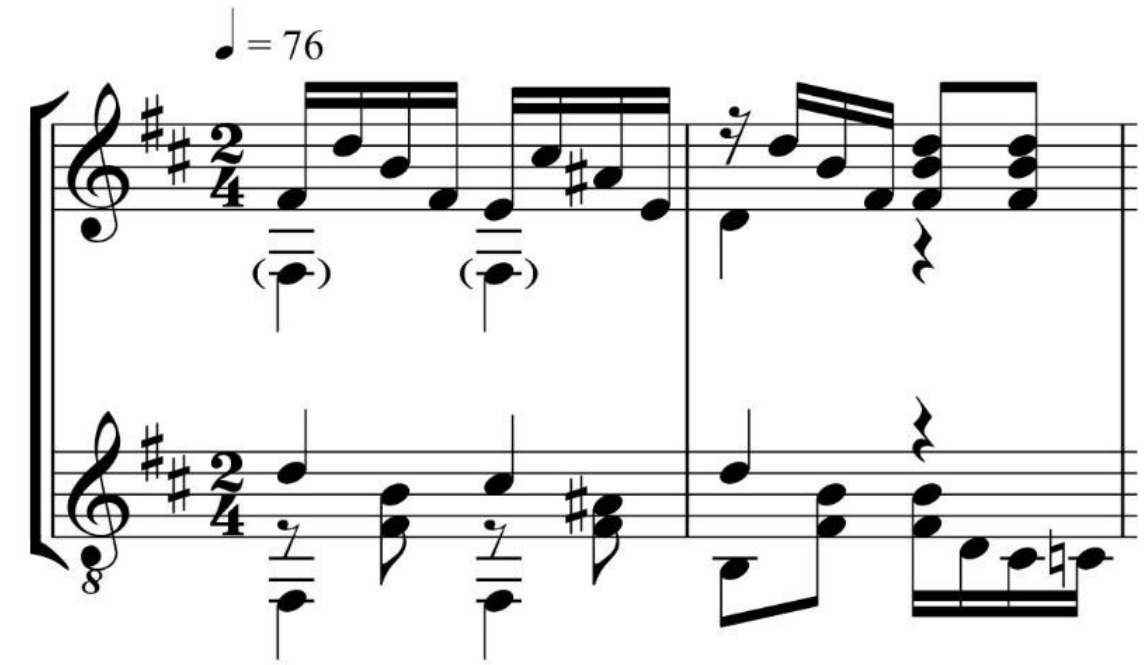

Fig.27: Primeiro compasso de Caranguejo e Colibri. Fonte: Elaboração dos autores (a).

- Ainda no 10 compasso, tomamos uma das mais difíceis e importantes decisões: o que deve ser destacado claramente como sendo o soprano (canto ou melodia). Sabemos que quando duas vozes, como é o caso do violão, ou mesmo dois instrumentos compartilham o mesmo pentagrama, suas hastes se voltam para fora dele. E aquilo que se reconhece como melodia é quase sempre indicado com a haste para cima. No caso de Colibri, parece nítida a presença de três vozes com o canto nas notas agudas Ré e Dó. Abaixo, a solução original do autor (ou talvez do gravador) e duas possibilidades de reescrita da passagem: 


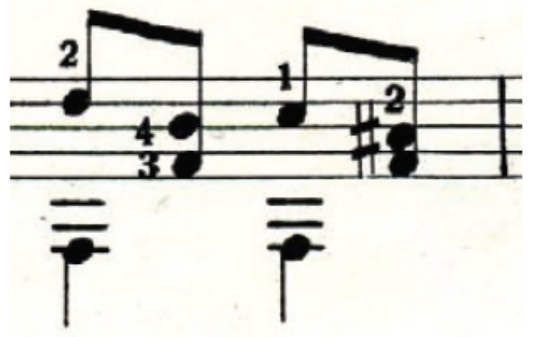

Solução original

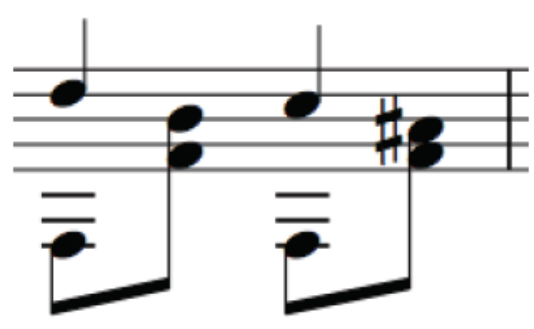

Solução melhor

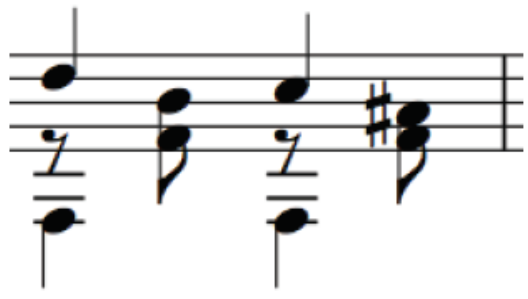

Solução ideal

Fig.28: Três possibilidades de escrita para o $1^{\circ}$ compasso de Colibri.

Fonte: elaboração dos autores (a).

- Compasso 2: além da melodia indefinida e do acompanhamento elevado ao status de melodia, temos a questão das hastes duplas, que podem, sim, ser um recurso útil para a clareza da escrita, mas aqui parecem desnecessárias e poluidoras. Cumpre notar que essa fórmula se repetiu em várias passagens no processo de editoração de ambas as peças, ocasiões em que assumimos invariavelmente a escolha pela partitura mais "limpa".

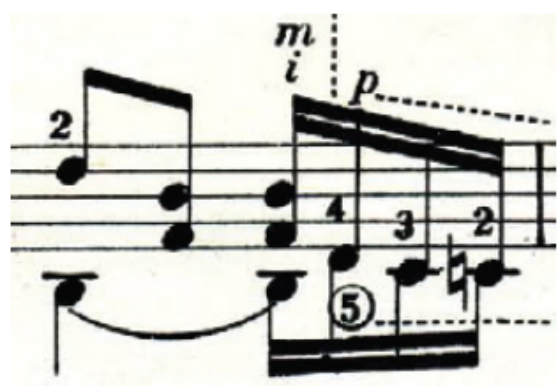

Solução original

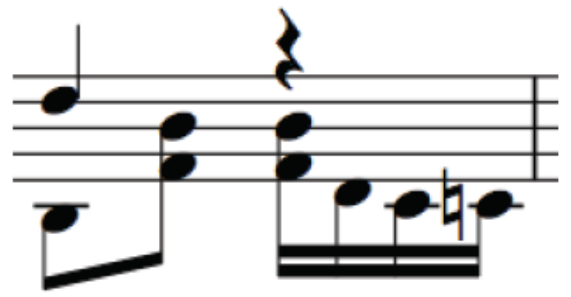

Solução em duas vozes

Fig.29: Duas possibilidades de escrita para o $2^{\circ}$ compasso de Colibri.

Fonte: elaboração dos autores (a).

- Compasso 5: mesmo no exemplo a seguir, uma fórmula que também aparece em diversas passagens, adotamos uma solução alternativa, híbrida: 


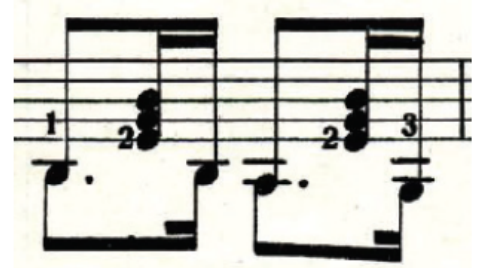

Solução original

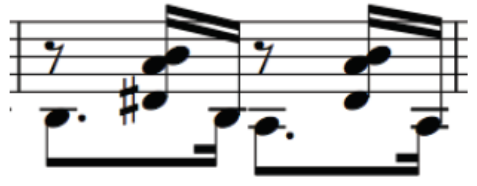

Apenas uma haste dupla, que além de evitar mais uma pausa, destaca a duração do acorde em semicolcheia.

Fig.30: Duas possibilidades de escrita para o $5^{\circ}$ compasso de Colibri. Fonte: elaboração dos autores (a).

- Compasso 7: se nos compassos anteriores as hastes duplas até certo ponto se explicam, aqui os argumentos para sustentar a sua permanência parecem ainda mais frágeis:

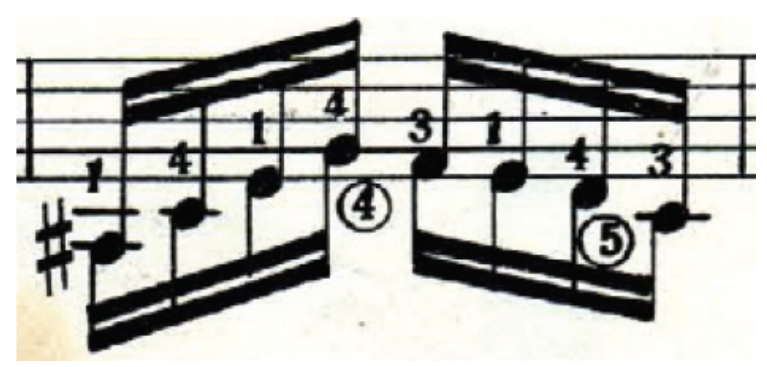

Fig.31: Compasso 7 de Colibri. Fonte: Cortez ([s.d.]).

Nesses casos, é possível aplicar uma dentre as seguintes soluções, dependendo do caso:

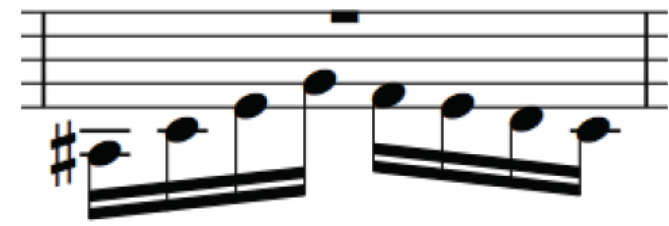

Adotar a sequência como sendo frase do baixo, marcando a primeira voz com pausa.

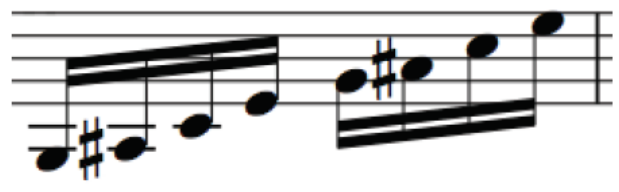

Adotar as regras da grafia musical

Fig.32: Duas possibilidades de escrita para compassos cujas notas foram grafadas com duas hastes (para cima e para baixo). Fonte: elaboração dos autores (a).

- Compassos 8 e 13: como desdobramento da questão anterior, entendemos que soluções como as seguintes, com hastes duplas envolvendo uma nota branca, sejam especialmente desaconselháveis: 

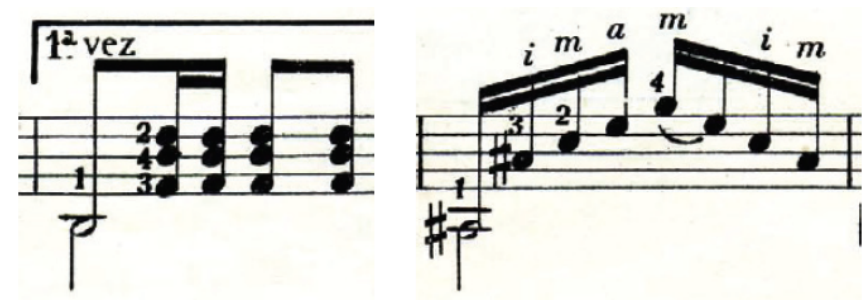

Fig.33 e 34: Compassos 8 e 13 de Colibri.

Fonte: Cortez ([s.d.]).

Elencamos alternativas possíveis, dentre as quais optamos por seguir como modelo a que se encontra em posição central:
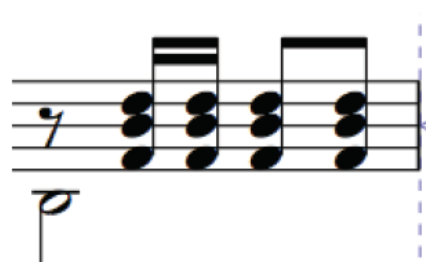
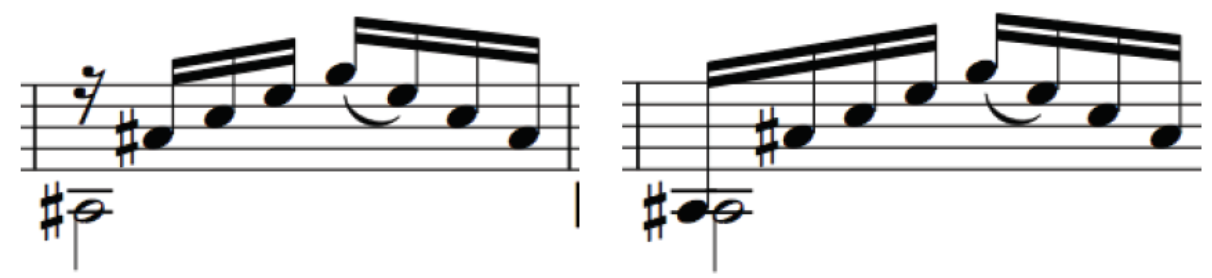

Fig.35: Possibilidades de escrita para os compassos 8 e 13 de Colibri.

Fonte: Elaboração dos autores.

- Sobre a indicação gráfica da pestana, geralmente através desse recurso podemos pressionar duas, três, quatro, cinco ou seis cordas do violão. Para tanto, tradicionalmente utilizamos apenas dois sinais de representação: C e . A editora Legato adota, há muitos anos, uma solução que julgamos mais precisa e eficiente: um algarismo romano indicando a casa e um índice, em arábico, expressando o número de cordas abrangidas pela pestana, além da linha que indica a extensão do recurso:

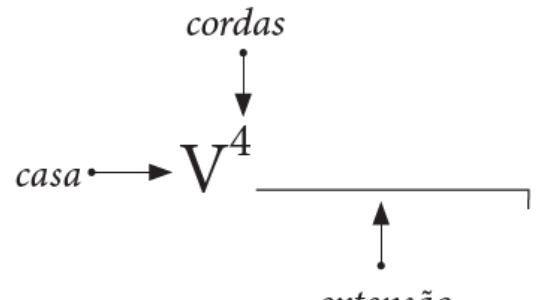

extensão
Esse método indica claramente a casa e o número de cordas a serem pressionadas.

Fig.36: Critério para a indicação de pestanas na edição de Colibri e Caranguejo. Fonte: elaboração dos autores (a).

De maneira geral, o trabalho de Melchior Cortez na junção dos conteúdos musicais já havia sido realizado de forma precisa, instilando uma consistente organicidade entre as peças. Com a descoberta do manuscrito de Caranguejo na Coleção Ronoel Simões e a edição moderna realizada pela Editora Legato dentro da "Coleção Humberto 
Amorim - partituras raras para violão", o resultado da combinação destes dois choros pioneiros do repertório brasileiro para violão pode finalmente ser avaliado pela comunidade acadêmica e artística do nosso instrumento.

\section{Considerações finais}

O repertório para violão escrito no Brasil ao longo do século XIX e primeiras décadas do século XX ainda é infimamente conhecido. Neste período, os primeiros choros para o instrumento de que tínhamos notícias se concentravam em alguns poucos nomes e obras, especialmente Heitor Villa-Lobos, com o Choros n. 1 e o Chorinho, este último integrante da Suíte Popular Brasileira. Outras partituras e documentos relacionados ao tema foram recentemente localizados, mas não apresentam data de composição ou cópia.

Este artigo é mais uma tentativa de contribuir para o conhecimento e a difusão do repertório para violão produzido no Brasil do século XIX até a década de 1930, pautando, relacionando e editando dois choros pioneiros que, até o momento, tinham suas genealogias desconhecidas: Colibri e Caranguejo. Paralelamente a este objetivo principal, buscamos apresentar um breve histórico das peças, traçar informações preliminares sobre seus autores (ambos raramente mencionados nos estudos do campo), discutir de forma introdutória algumas das razões pelas quais poucos choros para violão deste período nos alcançaram, esboçar uma análise das intersecções do período entre o instrumento e o circo, bem como avaliar as dubiedades terminológicas que, naquele momento, pairavam entre as danças europeias e os emergentes gêneros urbanos brasileiros.

De Melchior Cortez, Colibri foi composto em 1912 e é um dos raros exemplos de choro publicados ainda nas primeiras décadas do século XX, através da principal editora musical argentina (Casa Romero y Fernandez), estabelecimento com representantes comerciais no Brasil e que detinha grande poder de circulação no continente (as partituras, inclusive, apresentam na capa a indicação de venda nas moedas brasileira e argentina). Na edição solo da peça, o compositor expressa que aquele era um choro que também poderia ser tocado com outro, Caranguejo, obra que havia inspirado a sua realização.

De Francesco Rosa, o Gadanho, Caranguejo foi mais um dentre os infindáveis nomes soltos (de obras e/ou autores/as) que compõem as diversas trajetórias do instrumento no Brasil. Descoberto no arquivo passivo da Coleção Ronoel Simões, um manuscrito da peça com caligrafia de Melchior Cortez finalmente nos permitiu desvendar o entrelaçamento destes dois choros, a partir da identificação e avaliação de seus aspectos integradores e complementares. A edição das obras em versão para duo (tal qual imaginada por Cortez) nos ofereceu uma ideia do quão a investigação em torno do repertório pioneiro concebido no Brasil merece ser continuamente aprofundada, uma que vez que isso pode não somente alargar o entendimento de nossas práticas de outrora, mas também (e sobretudo) possibilitar que novas peças possam paulatinamente ser incorporadas na literatura de nosso instrumento. 


\section{Referências}

ALMEIDA, Renato de. História da música brasileira. 2. ed. Rio de Janeiro: F. Briguiet \& Comp., 1942.

AMORIM, Humberto. Melchior Cortez e a Academia Brasileira de Violão: uma página do ensino do instrumento na primeira metade do século XX. Vórtex, Curitiba, v. 6, n. 1, p. 1-27, 2018a.

AMORIM, Humberto. Melchior Cortez: um precursor do violão de concerto no Rio de Janeiro. Resonancias, Santiago (Chile), v. 22, n. 43, p. 13-42, jul./nov. 2018, 2018b.

AMORIM, Humberto. Idiomatismos na produção para violão de Melchior Cortez. Debates (UNIRIO), Rio de Janeiro, n. 21, p. 43-79, nov. 2018c.

AMORIM, Humberto. Três obras didáticas de Melchior Cortez (1882-1947): o violão entre os métodos clássicos e a Escola Moderna. Opus, v. 26, n. 1, p. 1-32, jan./abr. 2020.

ARAGÃO, Pedro de Moura. O baú do animal: Alexandre Gonçalves Pinto e o choro. Tese (Doutorado em Música). Centro de Letras e Artes, Universidade Federal do Estado do Rio de Janeiro, Rio de Janeiro, 2011.

BARROS, Josué de. Gemidos d'Alma: valsa. Rio de Janeiro: Sampaio Araújo \& Ca, 1930. Partitura.

BOCCIA, Leonardo V. A troca da clave: sobre a notação natural da música para violão, um guia completo de referência. Salvador: edição do autor, 1997.

BORGES, Luís Fabiano Farias. Transformações Estilísticas do Choro: o Idiomatismo do Violão de Sete Cordas, da Consolidação a Raphael Rabello. Dissertação (Mestrado em Música). Universidade de Brasília, Brasília, 2008.

BORGES, Luís Fabiano Farias. As Transformações das Formas Musicais do Choro. In: Anais do IV Encontro da ABET (Associação Brasileira de Etnomusicologia). Universidade Federal de Alagoas. 2008b, p. 60.

BORGES, Luís Fabiano Farias. O Violão de Sete Cordas no Brasil: de Tute a Raphael Rabello. Latvia: Novas Edições Acadêmicas, 2019.

BORGES, Luís Fabiano Farias; VOLPE, Maria Alice. O Violão Sete Cordas no Choro Tradicional e no Choro Não Tradicional. Revista Vórtex, Curitiba, v.8, n.3, p. 1-37, 2020. 
BRAGA, Luiz Otávio. O Violão de Sete Cordas. 2ำed. Rio de Janeiro: Lumiar Editora, 2004.

CARELLI, Mário. Carcamanos e Comendadores. Os italianos de São Paulo: da realidade à ficção. São Paulo: Editora Ática, 1985.

CARNEIRO, Josimar. A Baixaria no Choro. Dissertação de Mestrado (Música). Universidade Federal do Estado do Rio de Janeiro, 2001.

CARVALHO, Hermínio Bello de. Mudando de conversa. São Paulo: Martins Fontes, Espaço e Tempo, 1988.

CARVALHO, Hermínio Bello de. O canto do pajé: Villa-Lobos e a música popular brasileira. Rio de Janeiro: Espaço e Tempo, 1988.

CASTRO, Marcos Sampaio de. Bixiga: Um bairro afro italiano. São Paulo: Annablume, 2008.

CAZES, Henrique. Choro: Do quintal ao Municipal. 3ª ed. São Paulo: Ed. 34, 2005 [1998].

Correio Paulistano, São Paulo, ano XLII, n. 14916. 18 fev. 1905, p. 2.

CORTEZ, Melchior. Colibri. Buenos Aires: Casa Romero y Fernandez, [s.d.]. Partitura.

COSTA, Eliene B. A. Um estudo das comédias mágicas O Chico e o Diabo e Os Irmãos Jogadores, de Benjamim de Oliveira. Repertório, Salvador, v. 13, n. 15, p. 111-128, 2010.

COSTA, Rodrigo Heringer. Além do regional: a heterogeneidade de formações e instrumentos aplicados à performance do choro na passagem do século XIX ao XX. In: XXX Congresso da Associação Nacional de Pesquisa e Pós-graduação em Música, 2020, Manaus. Anais... Manaus: Universidade Federal do Amazonas, 2020, p. 1-12.

DELL'ARA, Mario. La chitarra antica, classica e romantica. Ancona: Bèrben, 1988.

Diário de Notícias, Música, Rio de Janeiro (RJ), Ed. 1007, 30 mar. 1933, p. 9.

Diário do Rio de Janeiro, Rio de Janeiro (RJ), 17 jan. 1828, p. 3.

GOULD, Elaine. Behind bars: the definitive guide to music notation. London: Faber Music, 2011.

JEFFERY, Brian. Fernando Sor: the complete works for guitar in fac-símiles of the original editions. 10 vol. London: Tecla, 1987. 
Jornal do Brasil, Rio de Janeiro, Movimento do Porto, Ed. 352, 18 dez. 1907, p. 5.

LIMA, Lurian J. R. da Silva. Suíte Popular Brasileira na trajetória de Villa-Lobos: "arte", "povo" e uma suíte "à brasileira". Dissertação (Mestrado em Música). Departamento de Artes/ Universidade Federal do Paraná, Curitiba, 2017.

LISBOA JUNIOR, Luiz Américo. Da modinha ao sertão: vida e obra de Catulo da Paixão Cearense. São Luís: Instituto, 2016, iconografia CD Anexo.

LIRA, Mariza. Brasil sonoro: gêneros e compositores populares. Rio de Janeiro: Editora A Noite, 1938.

LLANOS, Carlos Fernando Elias. Nem erudito, nem popular: por uma 'identidade transitiva' do 'violão brasileiro'. Tese (Doutorado em Música), Escola de Comunicação e Artes, Universidade de São Paulo, São Paulo, 2018.

MACHADO, Cacá. O enigma do homem célebre: ambição e vocação de Ernesto Nazareth. São Paulo: Instituto Moreira Salles, 2007.

MATEUS, Marlos. O Comportamento Interpretativo do violonista Dino Sete Cordas (1918-2006) em diferentes contextos de atuação no choro. Dissertação (Mestrado em Música Hispana). Facultad de Filosofía y Letras, Universidad de Valladolid, 2017.

O Commercio de São Paulo, São Paulo (SP), 15 abr. 1905.

PALÓPOLI, Cibele. Violão velho, Choro novo: processos composicionais de Zé Barbeiro. Tese (Doutorado em Música), Escola de Comunicação e Artes, Universidade de São Paulo, São Paulo, 2018.

PARAGUASSÚ. Org. Neide Lopes Ciarlariello. Baú da Saudade. São Paulo: Matarazzo, 2016.

PAULETTI, Ricardo. Apostila da Oficina de Prática de Choro. Itajaí: Edição do autor, 2015.

PENTEADO. Jacob. Belenzinho, 1910. São Paulo: Carrenho Editorial, 2003.

PINTO, Alexandre Gonçalves. Choro: reminiscências dos chorões antigos. 3a ed. comentada, revisada e ilustrada. Rio de Janeiro: Acari Records, 2014 [1936].

PUJOL, Emilio. Escuela razonada de la guitarra, libro 1ํ. Buenos Aires: Ricordi, 1991 [1956].

RAMOS, L. C. O violão de 6 cordas e as habilidades de acompanhamento no choro.

Dissertação (Mestrado em Música). Universidade de Brasília, Brasília, 2016. 
SANDRONI, Carlos. Feitiço decente: transformações no samba no Rio de Janeiro (1917-1933). 2. ed. Rio de Janeiro: Zahar, 2012.

SCARLATTI, Domenico. Sonata K. 87-L. 33. Transcrição de Sérgio Abreu. São Paulo: Ricordi, 1987. Partitura.

SĖVE, Mário. Choro: gênero ou estilo? In: XXVI Congresso da Associação Nacional de Pesquisa e Pós-graduação em Música, 2016, Belo Horizonte. Anais... Belo Horizonte: UEMG, 2016, p. 1-10.

SĖVE, Mário. O choro no estilo sambado: padrões rítmicos e fraseado musical. Debates, Rio de Janeiro, n. 17, p. 219-249, nov. 2016b.

SILVA, Erminia. O circo: sua arte e seus saberes: o circo no Brasil do final do século XIX a meados do XX. (Dissertação de mestrado) - Instituto de Filosofia e Ciencias Humanas, UNICAMP, 1996.

SILVA, Erminia. As múltiplas linguagens na teatralidade circense: Benjamim de Oliveira e o circo-teatro no Brasil no final do século XIX e início do XX. (Tese de doutorado) Instituto de Filosofia e Ciencias Humanas, UNICAMP, 2003.

SOR, Fernando. Fantasia op. 7. Paris: Meissonier, 1814. Partitura.

TINHORÃO, José Ramos. História social da música popular brasileira. Editora 34, 1998.

TINHORÃO, José Ramos. Os sons que vêm da rua. São Paulo: Editora 34, 2005.

UBIETA, Enrique. New York Rush: theme of the award-winning film 'El Super'. New York: Schirmer, 1979. Partitura.

VASCONCELOS, Ary. Carinho etc.: história e inventário do Choro. Rio de Janeiro: Editora do Livro, 1984.

VILLA-LOBOS, Heitor. Aria de la Bachianas Brasileiras no 5 pour soprano e ensemble de violoncelles. Adaptação de Roland Dyens. Paris: Henry Lemoine, 1992. Partitura.

ZAGURY, Sheila. Os grupos de Choro nos anos 90 no Rio de Janeiro: suas re-leituras dos grandes clássicos e inter-relações entre gêneros musicais. Tese (Doutorado em Música). Instituto de Artes, Universidade Estadual de Campinas, Campinas, 2014. 